\title{
Territori i relacions institucionals a la Catalunya del Sis-cents. Tres estudis de cas a partir dels processos de la Visita del General de Catalunya
}

\section{Institutional relations and territory in 17th Century Catalonia. Three case- studies from the Visita of the General of Catalonia judicial processes.}

\author{
RICARD TORRA \\ ricard.torra.prat@gmail.com
}

Universitat Autònoma de Barcelona

\begin{abstract}
Resum: Aquest article analitza tres casos diferents jutjats i sentenciats per la Visita del General de Catalunya durant les primeres dècades del segle XVII. L'estudi d'aquests processos ens permet acostar-nos al paper que tingué la institució fiscalitzadora a l'hora de controlar els oficials públics de la Diputació del General de Catalunya, observar-ne el desplegament arreu del territori i, finalment, sintetitzar quin era l'estat de les relacions entre la Diputació del General i la Visita del General just acabada la Guerra dels Segadors. Els dos primers casos s'emmarquen dins de la Visita duta a terme entre 1629 i 1630 i, més concretament, en la inspecció forana que els delegats designats pel consistori central de Barcelona dugueren a terme a la col lecta (i. e. demarcació fiscal) de Vilafranca de Conflent. El tercer cas té lloc pocs anys després del final de la Guerra dels Segadors (1640-1652), essent-ne els actors principals el consistori dels diputats i oïdors de comptes del trienni de 1654-1656 i els visitadors de 1654-1655.
\end{abstract}

Paraules clau: Història institucional, Generalitat de Catalunya, Visita del General, Monarquia Hispànica, segle XVII.

\begin{abstract}
This article studies three different cases judged by the Visita of the Generality of Catalonia within the first decades of the 17th Century. Thanks to its study, we can comprehend the role developed by the Visita in controlling the actions of the public officers of the Generality of Catalonia during the whole century, how the Generality was established around the territories of the Principality of Catalonia and the political relations amongst the major institutions in Catalonia in the mid-1650's. The first two cases that we want to analyse took place during the inspection conducted by the Visita of the Generality of Catalonia of 1629-1630 within the tax district of Vilafranca de Conflent, which focused their attention on its public officers. The third case, which took place after the conclusion of the Reaper's War (1640-1652), pays particular attention to the relation between the diputats and the oïdors de comptes of the Generality of Catalonia of 1654-1656, the commanders of the institution, and the visitadors of 1654-1655.
\end{abstract}

Keywords: Institutional history, Generality of Catalonia, Visita of the Generality of Catalonia, Spanish Monarchy, 17 th Century. 
Ricard Torra. Territori i relacions institucionals a la Catalunya del Sis-cents. Tres estudis de cas a partir dels processos de la Visita del General de Catalunya

\section{Introducció}

L'ús de fons judicials d'època moderna -especialment processos-a l'hora d'estudiar temàtiques tal vegada llunyanes com ara són el funcionament de «l'estat» modern o la pràctica quotidiana dels operadors jurídics ha gaudit d'una atenció historiogràfica notable les darreres dècades (Hespanha 1989; Olivares 2000; Capdeferro 2012 i 2017; Capdeferro \& Serra 2015). Això és especialment cert pel que fa a l'estudi de les institucions fiscalitzadores dels oficials públics de la Monarquia Hispànica dels Àustria. En aquest sentit, els processos de Juicios de Residencia, Pesquisas i Visites han estat utilitzats per diversos autors -especialment pel que fa a les visites de matriu castellana- per analitzar l'organització política de la monarquia (Rovito 1981; Garriga 1991; Herzog 2000; Peytavin 2003), les lluites faccionals ocorregudes durant els canvis de govern a la cort del rei (Gómez González 2016; Malaprade 2017), les relacions entre el món local i el rei (Felipó 2003), l’estudi del fenomen de la corrupció política (a mode de balanç d’aquesta qüestió: Andújar \& Feros \& Ponce 2017) o, senzillament, l'anàlisi dels aspectes processals d'aquestes institucions (González Peinado 2010).

Quant a l'àmbit territorial del Principat de Catalunya, les investigacions dedicades a les visites, val a dir que, en comparació amb les castellanes, compten amb un recorregut menys extens. D'entrada, caldria diferenciar entre -almenys- tres grans famílies d'organismes fiscalitzadors en funció de la jurisdicció a la qual aplicaven. En primer lloc, la Visita Reial, que com bé indica el seu nom fou la institució que des de les Corts Catalanes de 1599 s'encarregà de visitar els oficials reials que no «purgaven taula» (Lalinde 1965; Ferro 1999: 404-406), això és, la plana major de la oficialitat reial present al Principat. ${ }^{1}$ Segonament, la Visita del Consell Barceloní, dedicada, en aquest cas, a fiscalitzar els membres del govern barceloní durant sis mesos un cop finalitzava llur mandat, tot coincidint amb l'entrada d'un nou consistori a la ciutat. ${ }^{2}$ En darrera instància, la Visita del General de Catalunya, organisme dirigit a fiscalitzar l'activitat dels oficials públics de la Diputació del General de Catalunya durant nou mesos coincidint amb l'inici d'un nou trienni i que, a diferència de les dues institucions precedents, compta amb una literatura tal vegada més abundant, de la qual caldria destacar les obres de P. Llinàs (1990), J. Capdeferro (2007), E. Serra (2011a) o R. Torra (2014a; 2015; 2016).

Per definició, el procés d'una visita se centra en una o diverses querelles, que estudien una o diverses acusacions fetes bé per l'organisme fiscalitzador -acusacions a instància del fisc-, bé per un particular -acusacions a instància de part-, bé per ambdós i dirigides contra un oficial o grup d'oficials de l'entitat fiscalitzada. Tot plegat implica que, generalment, els processos tractin sobre la

1 La Visita Reial fou sancionada pel Capítol de Cort 5/1599. Constitutions fetes per la S.C.R. Magestat del Rey don Phelip Segon, Rey de Castella, de Aragó, etc. en la primera Cort celebrà als cathalans en la ciutat de Barcelona en lo Monastir de S. Francesch en lo any 1599, Barcelona, Gabriel Graells i Geraldo Dotil, 1603. Vegeu els ff. 21v-22r.

2 Arxiu Històric de la Ciutat de Barcelona (AHCB), Consell de Cent, Processos de la Visita, 1B.XVII-5, privilegi reial datat a 13-VII-1599. Aquest privilegi concentra l'evolució legislativa referent a la visita d’àmbit municipal, les primeres passes de la qual caldria remuntar a 1564. Cfr. AHCB, Consell de Cent, Ordinacions Originals, 1B.XXVI-26, camisa «1595-1598», doc. núm. 3 (22-II-1595).

SCRIPTA, Revista internacional de literatura i cultura medieval i moderna, núm. 13 / juny 2019 / pp. 212 - 242 ISSN: $2340-4841 \cdot$ doi:10.7203/SCRIPTA.13.15482 
Ricard Torra. Territori i relacions institucionals a la Catalunya del Sis-cents. Tres estudis de cas a partir dels processos de la Visita del General de Catalunya

(des)organització i les (dis)funcions que els visitadors constaten en el decurs de la seva inspecció. Així, els processos de la Visita Reial solen aportar-nos valuoses informacions sobre els oficials i institucions situades dins de l'àmbit jurisdiccional reial; els de la Visita del Consell Barceloní sobre aquells situats a l'òrbita de la jurisdicció municipal; i els de la Visita del General sobre l'oficialitat i l'organització institucional de la jurisdicció de la Generalitat.

L'objectiu d'aquest article és l'estudi de tres casos instruïts, jutjats i sentenciats per la Visita del General de Catalunya els quals, al nostre entendre, permeten d'una banda sintetitzar l'abast de la Visita en tant que institució dedicada a la fiscalització dels oficials de la Diputació del General de Catalunya i, de l'altra, comprendre succintament tant l'articulació territorial de la Diputació durant la primera meitat del segle XVII, com les dinàmiques institucionals dins de l'àmbit jurisdiccional de la Generalitat a mitjans del sis-cents. Els dos primers, s'emmarquen dins de la Visita duta a terme entre 1629 i 1630 i, més concretament, en la inspecció forana que els delegats designats pel consistori central de Barcelona ${ }^{3}$ dugueren a terme a la col lecta (i. e. demarcació fiscal) de Vilafranca de Conflent. En aquest sentit, s'analitzen els processos de les querelles número $121 \mathrm{i}$ 123: la primera d'elles dirigida contra Galderic Vilafranca, procurador fiscal de la Diputació local de Vilafranca de Conflent durant el trienni de 1626-1629; la segona, contra el mateix Vilafranca, Guillem Elies i Joan Felipó, notari i assessor, respectivament, també de la Diputació local de Vilafranca de Conflent durant el trienni de 1626-1629. Des del nostre punt de vista, ambdós casos exemplifiquen prou clarament la rellevància de les inspeccions foranes enviades arreu del Principat per la Visita del General de Catalunya durant les primeres quatre dècades del segle XVII, tant pel que fa a conèixer quin era l'estat real de l'administració de la Diputació del General a nivell territorial, com per reconduir les pràctiques irregulars amb l'objectiu d'homogeneïtzar el funcionament de la institució. ${ }^{4}$ El tercer cas té lloc pocs anys després del final de la Guerra dels Segadors (1640-1652). Així, els processos «bessons» de les querelles número 30 i 42 de la Visita del General realitzada els anys 1656-1657 esdevenen un mirador privilegiat per constatar tant les dificultats extremes que patiren les institucions situades dins de l'àmbit jurisdiccional de la Generalitat després d'anys d'endeutaments fruit de la guerra contra Felip IV, com les tensions sorgides entre visitadors i

3 Sobre el procediment, característiques i potencialitat de les visites foranes com a mecanismes per l'estudi de l'articulació territorial de la Diputació del General a l'època moderna, vid. Serra (2011a).

4 Vegeu, a tall d'exemple, l'imprès que els visitadors dedicaren a la figura dels taulers (oficials recaptadors) de la Generalitat amb aquest objectiu: Summari dels càrrechs y obligations dels collidors, taulers o receptors dels drets de la Generalitat del present Principat de Cathalunya y Comptats de Rosselló y Cerdanya, per Capitols de Corts, Ordinations del Generals y per sentèncias de visitas inposadas, Barcelona, Catarina Matevad, 1657. Hem utilitzat l'exemplar disponible a Biblioteca Universitària de Barcelona (BUB), 07 B-58/4/24. De fet, entre 1600 i 1714 la Visita del General de Catalunya dictà un total de 3.368 sentències, 1.770 de les quals -el 52,55\% del total- afectaren als oficials situats a fora de la Col lecta de Barcelona, controlada directament pels diputats i oïdors de comptes. Aquest fet implica, al nostre entendre, la importància que tingué la fiscalització del territori dins de l'àmbit competencial de la Visita -sobre els registres consultats per extreure aquestes dades, vegeu la nota 48. Finalment, caldria afegir que Mireille Peytavin (2003:171) ja evidencià aquesta qüestió en el seu treball sobre el paper jugat per les visites dins de l'àmbit polític i territorial de la Monarquia Hispànica dels Àustria.

SCRIPTA, Revista internacional de literatura i cultura medieval i moderna, núm. 13 / juny 2019 / pp. 212 - 242 ISSN: 2340-4841 · doi:10.7203/SCRIPTA.13.15482 
Ricard Torra. Territori i relacions institucionals a la Catalunya del Sis-cents. Tres estudis de cas a partir dels processos de la Visita del General de Catalunya

diputats arran del canvi de paradigma constitucional de resultes de la mercè de concessió de les Constitucions Catalanes feta, precisament, per Felip IV l'any 1653.

\section{Una tradició familiar problemàtica: Tres "Galderic Vilafranca" dificulten la identificació del veritable procurador fiscal de la Diputació local de Vilafranca de Conflent}

Com ja va apuntar fa uns anys M. Pérez Latre (2004: 109-198), la Diputació del General de Catalunya visqué un desenvolupament sense precedents durant la segona meitat del segle XVI, desenvolupament que estigué molt marcat per l'expansió de la institució arreu del Principat i Comtats de Rosselló i Cerdanya. En aquest sentit, diputacions locals i taularies foren clau per articular una xarxa d'oficials territorials encarregats tant de l'exacció dels drets del General -bolla de plom i drets d'entrada i eixida (Duran 2003: 9-10) - com d'exercir sobre el territori les prerrogatives de la institució pública en matèria de defensa de la legalitat vigent. Tanmateix, molt sovint aquesta ràpida expansió es basà més en mètodes de prova i error que no pas en la construcció d'un edifici institucional prèviament dissenyat amb minuciositat. Consegüentment, aquesta situació a voltes afavorí l'aparició de pràctiques poc transparents -quan no directament corrupteles- per part de l'oficialitat desplegada arreu del territori.

Amb l'objectiu de combatre aquesta situació, les Corts Catalanes de 1599 redissenyaren la Visita del General de Catalunya -institució fiscalitzadora els orígens de la qual caldria situar a les Corts Catalanes de 1431-1434 bo i dotant-la de les eines necessàries per afrontar els reptes derivats de la gran expansió que la Diputació havia patit durant la segona meitat del segle XVI. I, precisament, una de les característiques de la renovada institució fiscalitzadora fou la tramesa de delegats forans que, dirigits tothora des del consistori de Barcelona s'encarregaven de visitar les circumscripcions fiscals de la Generalitat, dividides en les veredes de Vic, Girona, Lleida i Tarragona (Gras 2000: 406-407). De l'acció dels delegats forans n’ha perviscut una notable producció documental que hom pot dividir succintament entre dietaris de les inspeccions foranes i processos dels oficials de les col lectes visitades. Ambdós testimonis documentals permeten apropar-nos d'una manera solvent a les interioritats de l'administració territorial de la Generalitat.

Com dèiem abans, el primer dels casos que analitzarem tingué lloc a la Diputació local de Vilafranca de Conflent, a finals de la dècada de $1620 .{ }^{5}$ La inspecció iniciada pels volts del 20 de setembre i encarregada a Josep Grau com a delegat forà, ben aviat estigué marcada per les incidències. Així, a 21 d'octubre de 1629, Grau escrigué als visitadors del consistori de Barcelona comunicant-los que degut a unes febres terçanes contretes a Perpinyà i de les quals no semblava poder recuperar-se,

5 Sobre la col lecta de Vilafranca de Conflent a finals del segle XVI, vid. Pérez Latre (2004: 265-267). Gràcies a les dades aportades per aquest autor, sabem que la col lecta la conformaven un total de cinquanta-vuit municipis, quatre dels quals -Vilafranca de Conflent, Puigbalador, Vinçà i Prada de Conflent-concentraven la totalitat d'oficials del General, això és, nou. A la capital de col lecta, Vilafranca de Conflent, a més del diputat local, durant la segona meitat del segle XVI hom hi identifica un assessor ordinari, un escrivà i dos taulers o collidors (Pérez Latre 2004: 267).

SCRIPTA, Revista internacional de literatura i cultura medieval i moderna, núm. 13 / juny 2019 / pp. 212 - 242 ISSN: 2340-4841 · doi:10.7203/SCRIPTA.13.15482 
Ricard Torra. Territori i relacions institucionals a la Catalunya del Sis-cents. Tres estudis de cas a partir dels processos de la Visita del General de Catalunya

havia decidit emprendre el camí de tornada a Barcelona. ${ }^{6}$ Pocs dies després, el consistori barceloní nomenà un nou delegat, Pere Montserrat, ${ }^{7}$ que entre els dies tres i deu de novembre de 1629 visità les terres de Conflent. De fet, l'arribada de Montserrat a Vilafranca de Conflent fou ben accidentada, ja que la comitiva de la Visita hagué d'abandonar l'hostal on s'havia hostatjat en primer terme tot resguardant-se al monestir de Sant Francesc, «per assegurar-me personas religiosas y desapacionadas que allí estava ab gran perill de la vida». ${ }^{8}$ La feina duta a terme pels visitadors, segons Montserrat, fou ingent: les investigacions realitzades contra l'assessor, l'escrivà i el procurador fiscal de la Diputació local de Vilafranca de Conflent l'havien obligat a fer-hi residència durant sis dies, treballant nit i dia «per ser molt lo cafen»; i encara afegia que «si aguèssam volgut donar lloc a quantas quexas no 's venian, hauríam agut menester un mes per averiguar-los, y per la brevedat del temps y molt negossi que 'ns resta a fer, me ha forsat no passar per tot sinó per lo més substancial».?

En aquest sentit, una d'aquestes querelles «substancials» fou la número 121, dirigida contra Galderic Vilafranca, paraire que exercia com a procurador fiscal de la Diputació local de Vilafranca de Conflent. ${ }^{10}$ L'escrit de l'acusació imputava a Vilafranca dos delictes: en primer lloc, el d'haver continuat exercint com a procurador fiscal conflentí malgrat que a inicis del trienni de 1626-1629 havia estat suspès de l'ofici per part dels dirigents de la Diputació del General, bo i aprofitant-se per fer-ho, del privilegi de procurador fiscal que havia obtingut el seu fill, de nom també Galderic. Segonament, el d'haver comès diverses composicions en l'exercici del seu càrrec, especialment pel que fa al cas d'un plat d'estany vell sostret a un tal Joan Antoni Cerdana, veí del lloc de Joncet, tot al legant que no havia pagat els drets del General pertinents. ${ }^{11}$

L'objectiu dels agents fiscalitzadors a l'hora de fortificar un procés consistia bàsicament en aportar documents que confirmessin les acusacions, o bé dos o més testimonis dels fets que les corroboressin. Per la primera de les acusacions del cas que ens ocupa -això és, l'exercici de l'ofici de procurador fiscal malgrat haver estat suspès pels dirigents de la Diputació del General- el fisc aportà proves documentals -el privilegi de procurador fiscal de la Diputació local de Vilafranca de Conflent expedit pels diputats i oïdors de comptes de Barcelona a favor de «Galderic Vilafranca,

6 Arxiu de la Corona d'Aragó (ACA), Generalitat, Sèrie VG, 90, Camisa 48, carta de Josep Grau als visitadors, datada a 21-X-1629. L'acompanyà Pere Gil de Frederich, escrivà de l'expedició que com Grau contragué terçanes.

7 Ibídem, nomenament de Pere Montserrat, datat a 26-X-1629.

8 Ibídem, carta de Pere Montserrat als visitadors, datada a 14-XI-1629.

9 Idem.

10 Segons M. Pérez Latre (2004: 183), l'ofici de procurador fiscal de la Diputació local estigué en clara expansió durant la segona meitat del segle XVI: abans de les Corts Catalanes de 1585 en trobem a les diputacions locals de Tortosa, Cervera, Girona, Tarragona, Lleida, Puigcerdà i Vilafranca del Penedès; no en tenim constància, emperò, pel cas de Vilafranca de Conflent. Les obligacions d'aquests oficials consistien en «acusar, denunciar, sol licitar i instar les causes i negocis criminals i civils del General portats davant del diputat local».

11 ACA, Generalitat, Sèrie VG, 90, Camisa 62, ff. 1r-1v.

SCRIPTA, Revista internacional de literatura i cultura medieval i moderna, núm. 13 / juny 2019 / pp. 212 - 242 ISSN: 2340-4841 · doi:10.7203/SCRIPTA.13.15482 
Ricard Torra. Territori i relacions institucionals a la Catalunya del Sis-cents. Tres estudis de cas a partir dels processos de la Visita del General de Catalunya

menon» $-{ }^{12}$ i testificals -les declaracions de Joan Barceló i Baptista Morer, ambdós de Vilafranca de Conflent, els quals confirmaren l'extrem que Vilafranca havia estat suspès durant l'exercici del seu càrrec «per algunas vellacarias», fet que no hauria impedit que acabés aconseguint que des de Barcelona s'expedís un privilegi de procurador fiscal en favor del seu fill. ${ }^{13} \mathrm{~A}$ més a més, durant la seva estada a Vilafranca de Conflent el delegat forà Pere Montserrat, interrogà tant a Galderic Vilafranca pare, com a Galderic Vilafranca fill, els quals bàsicament coincidiren en afirmar que mai s'havia suspès al primer i que el segon mai havia rebut el privilegi de procurador fiscal ni havia exercit com a tal. Encara més, Galderic Vilafranca pare assegurà que ell mateix signava com a Galderic Vilafranca «menor de dies [...] per tenir jo un germà major que jo [...] del mateix nom de Galderic». ${ }^{14}$

La segona de les acusacions, això és, la d'haver composat a Joan Antoni Cerdana, veí del lloc de Joncet, es fortificà només a partir de proves testificals. Així, a més a més de la relació dels fets exposada pel propi Joan Antoni Cerdana, el fisc presentà els testimonis de Jeroni Morer, de Vilafranca de Conflent -germà de Baptista Morer, potser? - i professor de medicina, i de Joan Cotxes i Faves, mercader de professió i receptor dels drets del General a la capital de les terres de Conflent. Segons la relació de Joan Antoni Cerdana, ${ }^{15}$ a finals del mes de setembre o principis del mes d'octubre de 1629 Galderic Vilafranca havia visitat el lloc de Joncet i tot inspeccionant casa seva, havia trobat un plat d'estany que no tenia la marca del General. ${ }^{16}$ Consegüentment, el procurador fiscal s'havia endut el plat al legant que la manca de marca evidenciava que es tractava d'un frau a la hisenda de la Generalitat. Poc conforme amb l'actitud del procurador fiscal, l'endemà mateix Cerdana es dirigí a la capital de les terres de Conflent amb l'objectiu de recuperar l'objecte decomissat. Tanmateix, el Galderic Vilafranca li exigí el pagament de certa quantitat monetària per recuperar-lo, que si bé inicialment fou fixada en deu lliures, gràcies a la intervenció de Jeroni Morer i Miquel Soler -aquest darrer diputat local de Vilafranca de Conflent durant el trienni de 16291632- finalment s'establí en tres reals, quantitat que un cop satisfeta li serví a Cerdana per recuperar el plat. Tant el testimoniatge de Jeroni Morer ${ }^{17}$ com el de Joan Cotxes i Faves -que havia exercit com a intermediari en el pagament dels tres reals per recuperar el plat d'estany- ${ }^{18}$ confirmaren la

12 Ibídem, f. 2.

13 Ibídem, ff. 5r-5v i 5v-6r, respectivament.

14 L’interrogatori de Galderic Vilafranca pare a Ibídem, ff. 6v-7v; el de Galderic Vilafranca fill a Ibídem, ff. 8r-9r.

15 Ibídem, ff. 3v-4r.

16 Un cop pagats els drets pertinents, les mercaderies se segellaven mitjançant encunys, normalment controlats per l'administració central de la Diputació del General. Tant Miquel Pérez Latre com Eva Serra han evidenciat la preocupació que existí entre els dirigents de la institució catalana per la proliferació d'encunys falsificats. (Pérez Latre 2004: 142; Serra 2011a: 235-245).

17 Ibídem, ff. 3r-3v.

18 Ibídem, ff. 4r-4v.

SCRIPTA, Revista internacional de literatura i cultura medieval i moderna, núm. 13 / juny 2019 / pp. 212 - 242 ISSN: 2340-4841 · doi:10.7203/SCRIPTA.13.15482 
Ricard Torra. Territori i relacions institucionals a la Catalunya del Sis-cents. Tres estudis de cas a partir dels processos de la Visita del General de Catalunya

declaració de Cerdana. En aquest sentit, especialment interessant resulta el punt de vista de Cotxes i Faves, el qual revelà que «dit procurador fiscal en presèntia de ell testimoni y de altres [digué] que lo haver-lo pres [el plat d'estany] era per un agravi que dit Cerdana li havia fet».

Un cop escoltades totes les parts i considerades provades les irregularitats en l'obtenció i exercici de l'ofici de procurador fiscal de la Diputació local de Vilafranca de Conflent per part de Galderic Vilafranca fill, els agents fiscalitzadors sentenciaren que el càrrec fos manllevat de la nissaga Vilafranca i posat a disposició dels dirigents de la Diputació del General de Catalunya «per la col lusió que se ha trobat haver-hi entre ells y per star molt diffamats de que no han servit ab legalitat lo dit offici». Pel que fa a les acusacions d'haver composat a Joan Antoni Cerdana, els Vilafranca foren finalment absolts, ben probablement perquè les irregularitats foren comeses durant el trienni de 1629-1632 i els agents fiscalitzadors de 1629-1630 només tenien capacitat per jutjar els delictes comesos durant el trienni de 1626-1629. ${ }^{19}$ Tanmateix, sabem del cert que gràcies a la inacció dels diputats i oïdors de comptes del trienni de 1629-1632 a l'hora d'executar les sentències de la Visita del General de 1629-1630, Galderic Vilafranca continuà exercint l'ofici de procurador fiscal de la Diputació local de Vilafranca de Conflent. ${ }^{20}$ De fet, durant la Visita del General de 1632-1633 fou novament condemnat a privació perpètua de l'ofici, en considerar-se provades les acusacions d'haver comès diversos «coetxos» en l'exercici de l'ofici i d'haver ignorat la privació decretada pels agents fiscalitzadors de $1629-1630 .^{21}$

\subsection{El desgavell de la Diputació local conflentina: testimonis falsificats, llanes no declarades, oficis simultanis i particulars extorsionats}

Les irregularitats comeses pels oficials de la Diputació local de Vilafranca de Conflent durant el trienni de 1626-1629, emperò, no només afectaven al procurador fiscal. Les investigacions dutes a terme pel delegat dels visitadors, Pere Montserrat, ben aviat evidenciaren noves disfuncions, totes elles generades a l'entorn de la figura de Joan Felipó i Guillem Elies, assessor i notari de la Diputació local, respectivament. Recollides a la querella número 123 de la Visita del General celebrada entre 1629 i 1630, foren bàsicament quatre: 1- La falsificació de les declaracions dels testimonis en el

19 ACA, Generalitat, Sèrie G, 8, 1, ff. 35r-35v. La qüestió de la limitació temporal dels visitadors a l'hora d'investigar querelles fou discutida a bastament durant la Visita del General celebrada els anys 1605-1606. En aquest sentit, un dictamen consultiu de doctors de la Reial Audiència recordà que la jurisdicció dels agents fiscalitzadors era extensible només al trienni finalitzat «y que los delcites que ‘s fan en lo corrent trienni tant per los officials antichs com per los nou provehits en lo loc dels suspesos no s poden castigar per los visitadors». ACA, Generalitat, Sèrie VG, 240, f. 157v. Citat per Torra (2016: 255).

20 De fet, els visitadors de 1632-1633 els condemnaren a pagar una multa de sis-centes lliures barcelonines en considerar provat que havien ignorat els seus deures en matèria d'execució de les sentències de la Visita. ACA, Generalitat, Sèrie G, 8, 1, $2^{\mathrm{a}}$ part, ff. 92r-93r.

21 Ibídem, ff. 63v-64v.

SCRIPTA, Revista internacional de literatura i cultura medieval i moderna, núm. 13 / juny 2019 / pp. 212 - 242 ISSN: 2340-4841 $\cdot$ doi:10.7203/SCRIPTA.13.15482 
Ricard Torra. Territori i relacions institucionals a la Catalunya del Sis-cents. Tres estudis de cas a partir dels processos de la Visita del General de Catalunya

marc del procés dut a terme a la Diputació local contra Sebastià Perarnau, prior de Cornellà, per no haver declarat unes llanes (i. e. ramat de bens); 2- La composició -o pacte a canvi d'evitar una multa- acordada amb el senyor de Jújols amb l'objectiu que aquest darrer pogués escapolir-se de la condemna que des de la Diputació local se li volia imposar per no haver manifestat unes llanes, valorada en 40 lliures barcelonines; 3- El fet que Joan Felipó exercís simultàniament com a oficial reial i oficial del General; 4- En darrer terme, diverses composicions comeses, en aquest cas, per Guillem Elies i Galderic Vilafranca, a la zona del Capcir durant el trienni fiscalitzat.

La primera de les acusacions de la querella núm. 123 s’instruí contra Joan Felipó i Guillem Elies, assessor i notari de la Diputació local de Vilafranca de Conflent, respectivament. En aquest cas en concret, les primeres inquisicions dutes a terme pels oficials de la Visita de 1629-1630 foren motivades per la denúncia de Sebastià Perarnau, prior de Cornellà. En efecte, Perarnau entregà al procurador fiscal de la Visita un paper escrit en el qual desgranava les actuacions que durant el mes d'octubre de 1628 l'assessor i el notari conflentins havien dirigit contra la seva persona, actuacions que estaven plenes «de maldats i vellaqueries», assegurava. Així, emprant les declaracions de quatre pagesos del lloc de Cornellà -Joan Pari, Francesc Berjoan, Pere Ollera i Francesc Colomer-, Felipó i Elies acusaven al prior de Cornellà d'haver defraudat la hisenda del General en no haver declarat diversos caps de bestiar de llana. Tanmateix, convençut de la seva innocència, Sebastià Perarnau esperà que el procediment fos publicat, moment en el qual s'adonà que «tot lo que stava continuat en les depositions dels testimonis contra ell ministrats ere falsament continuat y scrit y contra lo que los dits testimonis havian deposat y dit». Amb l'objectiu de demostrar la seva innocència, optà per una tàctica prou agosarada, això és, presentà com a testimonis de la defensa els mateixos quatre pagesos que Joan Felipó havia usat com a testimonis de l'acusació, amb la particularitat que en aquesta ocasió declararen «que ells no havian deposat ni dit lo que ab ses depositions offensionals se trobava continuat, sinó tot lo contrari» i encara reblaren «que les dites ses depositions no les havia $<\mathrm{n}>$ rebudes lo notari micer Elies, sinó lo propi micer Felipó sol». La jugada del prior de Cornellà fou tal vegada efectiva, ja que després de la nova declaració la causa fou desestimada; tal i com recollia el propi escrit de denúncia de Perarnau instat davant el procurador fiscal de la Visita, és força probable que Felipó i Elies decidissin deixar «de passar avant en la exequutió del dit frau» tot tement que la irregularitat comesa pels oficials conflentins «no arribàs a scièntia del consistori dels senyors diputats [de Barcelona]». ${ }^{22}$

La delació que el prior de Cornellà presentà davant el procurador fiscal de la Visita fou ràpidament acceptada, bo i considerant-se que els fets denunciats eren «dignes de punició». ${ }^{23} \mathrm{Cal}$ no oblidar que la Visita del General de Catalunya fou instituïda, precisament, amb l'objectiu de combatre totes aquelles actuacions dutes a terme pels oficials de la Diputació del General que fossin contràries

22 ACA, Generalitat, Sèrie VG, 90, Camisa 63, ff. 16r-16v.

23 Ibídem, f. 15 r.

SCRIPTA, Revista internacional de literatura i cultura medieval i moderna, núm. 13 / juny 2019 / pp. 212 - 242 ISSN: 2340-4841 · doi:10.7203/SCRIPTA.13.15482 
a les Constitucions Catalanes. ${ }^{24}$ Per la instrucció de la causa, els visitadors tornaren a citar com a testimonis de l'ofensa els quatre pagesos que ja havien protagonitzat el procés contra Sebastià Perarnau. A l'hora de declarar, Joan Pari, Francesc Berjoan, Pere Ollera i Francesc Colomer coincidiren en afirmar que tot plegat s'havia iniciat uns dies abans de la festivitat de Sant Lluc -18 d'octubre de 1628-, quan trobant-se tots quatre a la plaça del «Porqueril» de Vilafranca de Conflent, Joan Felipó -recordem-ho, assessor de la Diputació local conflentina- els manà que l'acompanyessin al seu estudi, on els demanà que s'informessin de la quantitat de bestiar que tenia el ramat del prior de Cornellà. Dels quatre, només Joan Pari i Francesc Colomer tornaren a citarse amb l'assessor -Francesc Berjoan assegurà que no el tornà a veure mai més i Pere Ollera que no hi tornà a parlar, car tenia «altres quefers»-; En el cas de Pari, mantingué una trobada informal amb Felipó durant la festivitat de Sant Lluc per comunicar-li que el pastor del prior Perarnau li havia assegurat que el ramat tenia uns cinc-cents caps de bestiar, mentre que Francesc Colomer comparegué davant de Felipó i el notari Guillem Elies a instància del diputat local de Vilafranca de Conflent, però «sols digué que havia entès dels pastors del bestiar de dit prior de Cornellà que y havia quatre o sinch cents caps». Així doncs, dels quatre testimonis, només Colomer sembla haver declarat davant l'assessor amb la presència del notari, mentre que tots coincidiren en afirmar davant dels visitadors que feien «molta maravella» de com s'havien tergiversat llurs deposicions. ${ }^{25}$

De fet, les deposicions dels pagesos de Cornellà en bona mesura coincideixen amb la declaració de Guillem Elies. ${ }^{26}$ En aquest sentit, el notari de la Diputació local de Vilafranca de Conflent confirmà als visitadors que no presencià el moment en que els pagesos foren interrogats per Joan Felipó ja que «ell, deposant, en aquest punt [...] estava ocupat». Semblantment, les transcripcions de les declaracions dels pagesos tampoc contenien les seves signatures ni els foren llegides; si bé en un primer moment Elies assegurà als visitadors que tot plegat era degut al fet que «heran pagesos y no sabien de scriura», poc després declarà que tot el procés el «copià com ho trobà de la mà de dit assessor escrit». I encara, quan els agents fiscalitzadors li preguntaren per quin motiu accedí a transcriure dins del procés les declaracions dels pagesos sense haver-les presenciat ni haver-les comunicat un cop transcrites, Elies respongué que Joan Felipó el pressionà assegurant-li que si

24 De fet, els agents fiscalitzadors es consideraven a si mateixos garants de l'ordre politicoconstitucional vigent, element que recolliren en diverses de les obres que publicaren durant el segle XVII. A tall d'exemple, en els impresos que dedicaren als oficials de la Diputació del General i les Galeres de la Generalitat, respectivament, els visitadors s'intitularen «zelants lo bé comú de la Generalitat», tot recordant que l'objectiu que els havia conduït a publicar ambdues obres no era altre que assegurar que els oficials públics «administren sos officis ab la perfectió convé al bé públic y utilitat de la Generalitat». Cfr. Capitols resultants de las sentèntias fetas per los molt illustres senyors visitadors del General de Cathalunya acerca dels càrrecbs dels officials de la Casa de la Deputació y General de Barcelona y altres publicades en lo any MDCXXI, Jeroni Margarit, Barcelona, 1621. L'exemplar utilitzat es pot consultar a la Biblioteca de la Universitat de Barcelona (BUB), Fons Antic, 07 B-58/4/8. Sobre les Galeres del General, vegeu Llobet (1990), Serra (2006) i Torra (2017).

25 El testimoni dels pagesos a ACA, Generalitat, Sèrie VG, 90, Camisa 63. La declaració de Joan Pari als ff. 18r-19r; la de Francesc Berjoan als ff. 19r-20r; la de Pere Ollera als ff. 20r-20v; finalment, la de Francesc Colomer al f. $21 \mathrm{r}$.

26 La declaració a Ibídem, ff. 29v-36r.

SCRIPTA, Revista internacional de literatura i cultura medieval i moderna, núm. 13 / juny 2019 / pp. 212 - 242 ISSN: 2340-4841 · doi:10.7203/SCRIPTA.13.15482 
Ricard Torra. Territori i relacions institucionals a la Catalunya del Sis-cents. Tres estudis de cas a partir dels processos de la Visita del General de Catalunya

la causa no prosperava perquè ell es negava a anotar els testimonis al procés «podia recàurer en càrrega sua de ell, deposant, si dit frau se perdia per falta de prova». Per l'assessor, calia actuar prestament, “ perquè no prenent-se dits testimonis en dita occasió era sert que aprés no ss poria provar, per ser lo prior home cautelós y que ab dàvidas [sic] corromp qualsevol cosa, y que los dits pagessos heran hòmens pobras y fàcils de corrompre."27

Contràriament, la declaració de Joan Felipó davant el consistori de la Visita del General ${ }^{28}$ fou diametralment oposada tant a les versions dels pagesos de Cornellà $-\mathrm{i}$, per tant, també contraria a la versió de l'acusació-, com a les informacions aportades pel notari Guillem Elies. D'entrada, l'assessor de la Diputació local de Vilafranca de Conflent declarà que havia iniciat les investigacions sobre els ramats del prior de Cornellà a instància d'un «acusador secret» el qual havia denunciat que els suara esmentats ramats - uns sis-cents caps de bestiar, segons sembla- estaven «devastant» els camps del lloc de Cornellà i, pitjor encara, no havien estat manifestats -i. e. declarats- al General. Segons Felipó, per sustentar els càrrecs, l'acusador secret li assegurà que enviaria quatre pagesos -Joan Paris, Francesc Berjoan, Pere Ollera i Francesc Colomer- a Vilafranca de Conflent perquè deposessin sobre l'afer. Poc després, els pagesos foren citats a declarar, però per sorpresa dels visitadors, l'assessor conflentí assegurà que les deposicions es dugueren a terme davant el notari Guillem Elies i que un cop foren transcrites, foren llegides als de Cornellà que les confirmaren! Encara més, preguntant-li els visitadors a Felipó que com era possible que Elies hagués participat en les declaracions dels pagesos de Cornellà si el mateix notari havia declarat davant els agents fiscalitzadors que es limità a transcriure dins del procés els interrogatoris ja elaborats per l'assessor, aquest darrer respongué que «no i sap ninguna cosa, antes està y persevera que dit Alias rebé y scrigué aquelles [deposicions] de sas pròprias mans en sa presèntia y ell, deposant, no escrigué tals ditxos ni ls donà scrits a dit Alias».

\footnotetext{
27 Ibídem, f. 31v. Sobre la idea de corrupció al llarg de la història és imprescindible l’obra de Buchan i Hill (2014). La tesi dels autors es basa en l'existència de dues concepcions sobre la idea de corrupció que s'anirien alternant al llarg de la història: l'una lligada a una qüestió eminentment moral, on el mot «corrupció» faria referència al procés de degradació d'un element en concret des del seu estat primigeni (també útil WAQUET 1991: 89). Contràriament, la segona concepció estaria lligada al servei públic, a un càrrec públic, i a grans termes es podria definir com la perversió d'aquest ofici amb l'objectiu d'obtenir-ne a canvi un benefici personal. En el cas de la declaració de Guillem Elies, podem veure com el fet de «corrompre» la declaració dels pagesos de Cornellà encara implicava una qüestió bàsicament moral - de l'estat primigeni, la primera declaració on es confirmaria la versió de l’advocat fiscal de la Diputació local de Vilafranca de Conflent, es passaria a una nova versió, la corrompuda, on els pagesos podrien desdir-se'n- sense relació amb l'ofici públic.
}

28 Ibídem, ff. 38r-42r. 
La segona de les acusacions fetes en el marc de la querella núm. 123 també es dirigí contra les persones de Joan Felipó i Guillem Elies i com en el cas del prior de Cornellà, també tenia els seus orígens en un procés aportat davant la Diputació local de Vilafranca de Conflent, en aquest cas per un suposat frau de llanes passades a França -sense haver estat declarades als oficials de la Generalitat, s'entén-. Tanmateix, a diferència del procés contra Sebastià Perarnau, en aquesta ocasió l'acusat de defraudar els drets del General -Pere Salvat, rector de Censà- sí que fou processat i, finalment, condemnat, sentència que fou confirmada pel consistori dels diputats i oïdors de comptes del General. ${ }^{29}$ Molt probablement, el cas no hauria aixecat les sospites dels visitadors si no hagués estat pel fet que el rector de Censà no fou l'únic acusat pels oficials conflentins; en efecte, a més a més de Pere Salvat, hom acusà del mateix delicte a Pere de Casanovas, senyor del lloc de Jújols, però a diferència del primer $-i$ malgrat ser el propietari dels ramats- finalment fou absolt.

Ben aviat, el cas aixecà les sospites dels veïns de Vilafranca, ja que com explicà als visitadors Joan Cotxes i Faves, receptor dels fraus del General a la capital conflentina, «se murmurà que per dita sentència de absoldre al de Jújols, micer Joan Philipó, assessor, y micer Guillem Alias, notari del General, ne havian hagut quatre-cents reals». ${ }^{30}$ En aquest sentit, el testimoni de Galderic Rebollet, jurista de Vilafranca de Conflent i assessor legal del senyor de Jújols, sembla haver redoblat les sospites dels visitadors. ${ }^{31}$ Sempre seguint la declaració de Rebollet, sabem que després que els membres de la Diputació local de Vilafranca de Conflent haguessin processat a Pere de Casanovas, aquest acudí a l'estudi de Rebollet per demanar-li consell. Després d'estudiar el cas minuciosament i d'adonar-se que «segons lo que resultava de la enquesta que me fonch comunicada, la defensa seria duptossa», Rebollet aconsellà al seu client que es reunís amb els membres de la Diputació local «per remediar que no pasàs avant dita causa ni s'i proferís sentèntia» i:

\begin{abstract}
entenguí després que caminant per aquest camí se hera remediat lo negossi quant al interès enperò del dit senyor de Juyols, significant-me que axò era estat fet entrevenint-hi algun interès o promesa feta als dits officials, que aprés corragué la veu entra la gent que aquex interès foran quatre-cents reals que 's donaren als officials que eran lo dit diputat local, micer Joan Felipó, assessor, y lo notari del concistori, micer Alias».
\end{abstract}

Tanmateix, la solució adoptada per uns i altres no convencé pas a Rebollet: segons sembla, en un primer moment hom acordà que a canvi de rebre els quatre-cents reals, els oficials de la Diputació local deixarien sense cloure el procediment contra el rector de Censà i el senyor de Jújols. Pel jurista conflentí «dexar en hubert la sentèntia que se havia de proferir en dita causa era molt desasartat»,

29 Concretament fou condemnat a pagar una multa de 138 lliures rosselloneses. Ibídem, s/f, paper inserit entre els ff. 25 i 26 .

30 Ibídem, f. 23r. Així mateix, Galderic Vilafranca assegurà que l'afer «fonch fama pública y ho és ara de present y en la present vila de Vilafranca». Ibídem, f. 24r.

31 Ibídem, ff. 24v-25v.

SCRIPTA, Revista internacional de literatura i cultura medieval i moderna, núm. 13 / juny 2019 / pp. 212 - 242 ISSN: 2340-4841 · doi:10.7203/SCRIPTA.13.15482 
Ricard Torra. Territori i relacions institucionals a la Catalunya del Sis-cents. Tres estudis de cas a partir dels processos de la Visita del General de Catalunya

ja que pels interessos del seu client era molt més viable que «lo absolgueran» ja que «altrament aventuraven que a la Visita fahedora los senyors visitadors denunciarien los procehiments de aquexa causa» 1 estant-hi involucrat Jújols «reinsidiria en lo matex treball y cuidado». És en aquest moment que és més que probable que a la Diputació local hom acordés condemnar al rector de Censà $\mathrm{i}$ absoldre el senyor de Jújols, com de fet acabà succeint. ${ }^{32}$ De totes maneres, tot sembla indicar que la maniobra que Joan Felipó dissenyà per evitar la condemna del senyor de Jújols era plenament legal: així, segons el testimoni del notari Guillem Elies, sabem que Felipó s'informà amb Joan Ros, advocat fiscal reial dels Comtats. Aquest li feu saber que les llanes manifestades a una taula del General no havien pas de pagar els drets d'eixida si no sortien del Principat i en cas que fos així, qui havia de pagar-los era el darrer propietari, ${ }^{33}$ en aquest cas el rector de Censà que, conxorxat o no amb el senyor de Jújols, fou qui tenia les llanes en propietat quan suposadament foren traspassades a França -al senyor de Colòbres, concretament-.${ }^{34}$ Comptat i debatut, des del punt de vista d'Elies l'acusació d'haver composat al senyor de Jújols a canvi de la seva absolució era quelcom «falcíssim» i «molt gran maldat y vellacaria», ${ }^{35}$ mentre que Joan Felipó assegurava que l'interrogatori del rector de Censà «no conté veritat [...] ni tal porà constar ab veritat, ni la reputació y fama és tala que per coetxos y altrament aja de torsar la justícia», tot recordant que mai havia rebut cap salari per instar tant aquesta com la resta de causes que havia conduït davant la Diputació local de Vilafranca de Conflent. $^{36}$

La tercera de les acusacions plantejades en el marc de la querella núm. 123 versà sobre la incompatibilitat d'exercir simultàniament oficis en les jurisdiccions reial i del General, respectivament, i només afectà a Joan Felipó, assessor de la Diputació local de Vilafranca de Conflent. ${ }^{37}$ D’una

32 De fet, sabem que fins i tot els membres de la Diputació local executaren a Pere Salvat requisant-li trenta-set càrregues de blat sense garbellar, que un cop triat valgueren unes 59 lliures barcelonines. Ibídem, s/f, paper inclòs entre els ff. 25 i 26.

33 Així ho disposava el Capítol 20 del Redreç de 1481, que també establia que les llanes només es poguessin manifestar a les taules de Barcelona, Tortosa, Perpinyà i Lleida. Cfr. Capitols dels drets del General del Principat de Cathalunya y Comtats de Rosselló y Cerdanya: fets per la Cort General, celebrada per la bona memòria del Catòlich Rey don Fernando Segon, en lo Capitol de la Seu de Barcelona a VIII de Octubre, any de la Nativitat del Senyor MCCCCXXXI, dins Capitols dels drets y altres coses del General del Principat de Cathalunya y Comtats de Rosselló y Cerdanya fets en Corts generals del any MCCCCXXXI fins en lo any MDLXIIII inclusive, $y$ dels drets que per pràctica y altrament se paguen, Casa Mathevat, Barcelona, 1670, ff. 8v-9r.

34 ACA, Generalitat, Sèrie VG, 90, Camisa 63, ff. 33v-34r i 35r-35v.

35 Ibídem, f. 33v.

36 Ibídem, f. 39v.

37 Les Corts Catalanes de 1599 legislaren sobre aquesta qüestió. En aquest sentit, tant el Capítol de Cort 54/1599 com el Capítol del Redreç 36/1599 estipularen que els oficials reials que volguessin participar en el procés d'elecció d'aquestes institucions haguessin de renunciar al seu ofici sis mesos abans de celebrar-se el procés d'elecció. El Capítol de Cort 54/1599 a Constitutions fetes per la... (1603), ff. 37v-38r. El Capítol del Redreç 36/1599 a Capitols per lo redrés del Generaly Casa de la Deputació de Cathalunya, fets en las Corts celebrades en lo Monestir de Sant Francesch de Barcelona per la S.C.R.M. del Serenissim Senyor Rey Don Felip II de Aragó y III de Castella, en lo any 1599, Rafel Figueró, Barcelona, 1704, pp. 63-65.

SCRIPTA, Revista internacional de literatura i cultura medieval i moderna, núm. 13 / juny 2019 / pp. 212 - 242 ISSN: 2340-4841 · doi:10.7203/SCRIPTA.13.15482 
Ricard Torra. Territori i relacions institucionals a la Catalunya del Sis-cents. Tres estudis de cas a partir dels processos de la Visita del General de Catalunya

banda, tal i com es desprèn de l'escrit de defensa del propi Felipó, durant el trienni fiscalitzat això és, el de 1626-1629- exercí com a jutge reial -jutge de la Cort del Veguer de Vilafranca de Conflent- i assessor del General. I si bé és cert que entre l'exercici d'un i altre càrrec passaren tres mesos, també ho és el fet que segons la legislació vigent n’havien de transcórrer sis. ${ }^{38}$ D’altra banda, diversos testimonis presentats per l'acusació semblen demostrar que Joan Felipó hauria començat a exercir com a advocat fiscal de la Cort del Veguer, fet que no s'hauria pogut jutjar en el marc de la Visita celebrada els anys 1629-1630, ja que es tractaria d'una qüestió inherent al trienni de 1629-1632 i, per tant, situada fora de la jurisdicció dels agents fiscalitzadors. ${ }^{39}$ Sigui com sigui, aquest fet tampoc sembla haver estat la principal motivació per la qual els agents fiscalitzadors privaren a Joan Felipó de l'ofici d'assessor de la Diputació local de Vilafranca de Conflent.

Els maldecaps dels oficials de la diputació local conflentina no s’acabaren aquí, però:

\begin{abstract}
Et dixit jo conech molt bé a micer Joan Felipó, assessor del diputat local de la present vila y collecta, y a micer Guillem Alias, nottari de dit consistori. Y he entès a dir públicament que estan en consuetut de fer molts coetxos y compositions per rahó de sos officis. Y en particular he vist jo, testimoni, que dit micer Alias, nottari, en compania del procurador fiscal, qui hera Galderic Vilafranca, dit lo bordagàs, un dia que aurà un any poch més o mancho [partiren] als llochs de Capsir y composaren als llochs [...] dos trentins del un y quatra del altre, ab motiu que ls volian executar per ordre dels senyors diputat $\mathrm{y}$ assessor perquè deian no avian manifestadas las lanas. Y viu jo que del lloch de Matamala ne agueran vuyt trentins y de Fontrabiosa tres trentins, Despusola dos trentins, de Careu set ducats, de Vila [...] quatra ducats, Formiguera dos trentins, de Real dos-cents reals de dos [...] y de altres que ara [no recordo]. ${ }^{40}$
\end{abstract}

Amb aquestes paraules es referí Francesc Teixidor, rector de Puigbalador, a la darrera de les acusacions que els visitadors plantejaren contra la plana major de l'oficialitat de la Diputació local de Vilafranca de Conflent en el marc de la querella núm. 123 de la Visita dels anys 16291630. L'explicació, prou clara i diàfana, coincidia amb la de Pere Salvat, rector de Censà, que en

38 ACA, Generalitat, Sèrie VG, 90, Camisa 63, f. 8b.

39 Els testimonis que confirmaren la dualitat d'oficis -advocat fiscal de la Cort del Veguer i assessor de la Diputació local conflentines- de Joan Felipó foren: Antoni Joan Cotxes i Faves, receptor del General a Vilafranca de Conflent: «és cosa pública en la present vila que lo dit micer Philipó [...] serveix lo offici de advocat fiscal del rey en la present vila, y ha ohit dir a alguns de la present vila que feyen maravella fos assessor de la Deputació tenint offici real» (Ibídem, f. 23v); Galderic Vilafranca, procurador fiscal de la Diputació local de Vilafranca de Conflent (ff. 23v-24r); Martí Prats, escrivent del notari de la Cort del Veguer de Vilafranca de Conflent, el qual hauria transcrit personalment el privilegi de Felipó (ff. 26r-26v); Diego Pasqual i de Cadell, germà de Francsc Pasqual i de Cadell, veguer de Vilafranca de Conflent (ff. 26v-27r); Jaume Casadevall, mercader conflentí (ff. 27r-27v).

40 Ibídem, ff. 27v-28r. Testimoni de Francesc Teixidor, rector de Puigbalador.

SCRIPTA, Revista internacional de literatura i cultura medieval i moderna, núm. 13 / juny 2019 / pp. 212 - 242 
Ricard Torra. Territori i relacions institucionals a la Catalunya del Sis-cents. Tres estudis de cas a partir dels processos de la Visita del General de Catalunya

el moment de denunciar les -sota el seu parer-irregularitats comeses en la sentència del cas de les llanes no declarades al General, no dubtà en assenyalar també les nombroses «composicions y coetxos» que l'assessor, el notari i el procurador fiscal conflentins haurien comès en l'exercici de les seves responsabilitats dins l'administració del General. I molt particularment el fet «que en lo any 1628 lo fill de Guillem Alias en companyia de Galderic Vilafranca, procurador fiscal, eran passats al loch de Capsir y de allí avian agut vuyt trentins de compositions». ${ }^{41}$

Altra vegada l'afer devia semblar prou important als visitadors que durant els interrogatoris fets a Guillem Elies i Galderic Vilafranca intentaren esbrinar fins a quin punt eren certes les paraules dels testimonis. D'entrada ambdós oficials negaren que l'objectiu de la seva visita a les terres del Capcir fos composar llurs habitants. Així, segons la declaració d'Elies, la inspecció l'hauria ordenat el veguer del Conflent, Francesc Pasqual i de Cadell bo i seguint les ordres del lloctinent general Miguel de los Santos de San Pedro, bisbe de Solsona. Per dur-la a terme, el veguer hauria aplegat una petita companyia d'homes entre els quals es trobava Josep Elies, fill del notari Guillem Elies, que hi acudí perquè el veguer els «digué que li fessan pler de anar ab ell, que se entretindrian y se passejarian per la montanya» i com que Josep Elies «hera fadrí y no tenia cafer, se n'anà ab ells y passejaren a la montanya de Mosset, y de aquí caigueran en Capsir». Preguntat sobre si Elies júnior havia actuat com a notari substitut d'Elies sènior durant la inspecció, aquest darrer assegurà fins a dues vegades que «lo dit Josep no anava per ningun negoci, sinó per passejar-se y divertir-se ab aquestos senyors, y no com a substitut seu ni altrament». ${ }^{42}$

Tanmateix, la versió de Galderic Vilafranca fou sensiblement diferent a la de Guillem Elies. En aquest sentit, segons el procurador fiscal conflentí l'actuació per la zona del Capcir no l'ordenà el veguer en persona, sinó que fou a instància del diputat local de Vilafranca de Conflent. Semblantment, a diferència d'allò declarat per Guillem Elies, Vilafranca assegurava que ell i Elies júnior havien compartit expedició, aquest darrer actuant com a notari d'aquesta. Sempre seguint el testimoniatge de Vilafranca, l'expedició per terres del Capcir en cap cas hauria consistit en composar-ne els habitants, sinó que hom acudí a la taula de Puigbalador, on el tauler els entregà un llistat de totes les persones que malgrat haver manifestat la possessió de llanes, no havien pagat els drets pertinents. Un cop obtingut el llistat, l'actuació dels oficials del General i els homes del veguer consistí a executar els defraudadors dels drets del General. ${ }^{43}$

41 Ibídem, s/f, paper intercalat entre els ff. 25 i 26. Testimoni de Pere Salvat, rector de Censà.

42 Ibídem, f. 34r-34v. Interrogatori a Guillem Elies, notari de la Diputació local de Vilafranca de Conflent.

43 Ibídem, ff. 36v-37v. Interrogatori a Galderic Vilafranca, procurador fiscal de la Diputació local de Vilafranca de Conflent.

SCRIPTA, Revista internacional de literatura i cultura medieval i moderna, núm. 13 / juny 2019 / pp. 212 - 242 ISSN: $2340-4841 \cdot$ doi:10.7203/SCRIPTA.13.15482 


\subsection{Un balanç provisional a l'espera de nous estudis: 1'administració del General i el territori a la primera meitat del segle XVII}

La sentència de la querella núm. 123 de la Visita de 1629-1630 fou severa. ${ }^{44}$ En aquest sentit, Joan Felipó, Guillem Elies i Galderic Vilafranca foren privats de l'ofici. Els dos primers, en considerar-se provada la denúncia del prior de Cornellà referent a la falsificació dels testimonis de Joan Pari, Francesc Berjoan, Pere Ollera i Francesc Colomer. ${ }^{45}$ Pel que fa a Galderic Vilafranca, hom tingué en compte, principalment, les irregularitats comeses en el marc de la querella núm. 121 -estudiada més amunt.

D’altra banda, tot sembla indicar que en el cas de la composició per les llanes del senyor de Jújols i el rector de Censà les explicacions dels oficials conflentins convenceren els visitadors. De fet, demostrar la composició era tal vegada complicat, ja que tant la principal part afectada, Pere de Casanovas, com els acusats negaren l'existència del pacte. ${ }^{46} \mathrm{I}$ encara, suposem que les declaracions de Guillem Elies avisant de la connivència entre el rector de Censà i el senyor de Colòbres i les dificultats que els agents del General tenien a l'hora de controlar els fraus en terra de frontera acabaren de convèncer els agents fiscalitzadors. ${ }^{47}$

Tampoc sembla haver estat tant rellevant a l'hora de suspendre Joan Felipó l'acusació d'haver servit com a oficial reial i oficial del General sense respectar el termini de sis mesos entre un $\mathrm{i}$ altre càrrec. Val a dir que aquesta fou una pràctica poc freqüent dins de l'univers d'acusacions fetes pels visitadors del General contra els oficials de la Diputació. Així, entre 1600 i 1714 hem detectat un total de vinti-quatre acusacions per aquesta qüestió, cosa que representà un $0,36 \%$ del total (6.597 acusacions). ${ }^{48}$

44 La sentència de la querella núm. 123 a ACA, Generalitat, Sèrie G, 8, 1, f. 45v-46r.

45 Pel que fa a Guillem Elies sabem que la sentència es feu efectiva, ja que a 13 de juliol de 1633 els diputats i oïdors de comptes del trienni de 1632-1635 enviaren el privilegi d'escrivà de la Diputació local de Vilafranca de Conflent al nou titular, Martí Prats, notari d'aquesta vila. En l'escrit, els dirigents de la Diputació del General recordaven que l'ofici d'escrivà de la diputació conflentina restava vacant per la sentència de la Visita promulgada pels visitadors de 16291630. ACA, Generalitat, Sèrie N, 849, ff. 59v-60v.

46 Pere de Casanovas declarà que, en efecte, durant el trienni de 1626-1629 s'instà una causa contra ell mateix i el rector de Censà davant el consistori de la Diputació local de Vilafranca de Conflent per un frau de llanes, encara que descartà conèixer cap altra qüestió relacionada amb la suposada composició pactada amb els oficials conflentins. ACA, Generalitat, Sèrie VG, 90, Camisa 63, f. 25v.

47 Guillem Elies assegurà que per executar la sentència contra el rector de Censà havien hagut de mobilitzar les tropes del veguer de Conflent, ja que «en aquexas fronteras no conexan el General, y que i anàs un official ni dos sols és sert los matarian, com se és vist en algun temps, y no són potents dits officials del General si no són asociat y tenint assistència del veguer. Y se és vist que anant algun official del General en la vila de Auleta, que és molt bax de la frontera, y trobant algunas càrregas de llana que la volian passar en Fransa, encarar-li los pedrenyals y volent-lo matar si no fos per algunas personas que s i posavan de per mig y ho divertiren. Y com lo dit rector de Sansà patia per aver fet plers, segons se diu, y acostumàs quiscun any passar llana en Fransa y aportar-la al senyor de Scolobra y ser lo dit lloc prop de Sansà, se tingué notícia que quant executarian al dit rector lo dit senyor avia de enviar gent per divertir la dita executió, y axí fonch manaster la dita acistència, que altrament ningú y hauria anat». Ibídem, ff. 35r-35v.

$48 \mathrm{La}$ base de dades sobre les sentències de la Visita del General d'on hem extret els nombres suara comentats l'hem

SCRIPTA, Revista internacional de literatura i cultura medieval i moderna, núm. 13 / juny 2019 / pp. 212 - 242

ISSN: 2340-4841 · doi:10.7203/SCRIPTA.13.15482 
Ricard Torra. Territori i relacions institucionals a la Catalunya del Sis-cents. Tres estudis de cas a partir dels processos de la Visita del General de Catalunya

Similarment, l'acusació dirigida contra Galderic Vilafranca i Guillem Elies suposant que havien composat a diverses persones durant la visita que feren a les terres del Capcir tampoc sembla haver tingut incidència en la sentència final. En aquest sentit, les explicacions tant del procurador fiscal com del notari evidenciaren que lluny de tractar-se d'una inspecció destinada a enriquir-los, fou dirigida des d'instàncies superiors. Comptat i debatut, si com assegurava Guillem Elies la visita de les terres del Capcir l'havia convocat el veguer a instàncies del lloctinent general, que s'hi haguessin comès o no delictes de composició era una qüestió situada fora de l'àmbit jurisdiccional de la Visita del General.

En definitiva, malgrat que la majoria d'acusacions dirigides contra els oficials del General en el marc de la querella número 123 foren per delictes de composició, la sentència definitiva només considerà provada la falsificació dels testimonis en l'acusació contra el prior de Cornellà dirigida per Joan Felipó, assessor de la Diputació local de Vilafranca de Conflent. ${ }^{49}$ Entre 1600 i 1714 hem registrat un total de 141 acusacions per composició dirigides contra oficials del General, cosa que representa el 2,13\% del total, xifres tal vegada discretes. Tanmateix, si ens fixem només en les acusacions fetes contra els oficials territorials de la Diputació del General les xifres són ben diferents. En aquest sentit, en el cas dels diputats locals entre 1600 i 1714 hom pot localitzar fins a 27 acusacions de composició, cosa que suposà el 23,27\% del total d'acusacions dirigides contra aquests oficials (116 acusacions). I les xifres són encara més divergents si observem el cas dels guardes del General, que entre 1600 i 1714 protagonitzen un total de 45 acusacions de composició, això és, el 45,91\% del total (98 acusacions). Així doncs, és possible que la oficialitat de la Diputació del General desplegada devers el territori tendís més que no pas els oficials de Barcelona a exercir llurs càrrecs circulant sobre la línia divisòria entre allò legal i allò il legal? O tal vegada estem davant uns habitants més bel licosos davant d'uns oficials el poder dels quals era molt més limitat en comparació al dels seus homòlegs barcelonins? Futurs estudis que analitzin les querelles dirigides contra els oficials del territori de manera sistemàtica hauran d'intentar respondre aquestes qüestions.

elaborada a partir del registre de sentències de la Visita del General: ACA, Generalitat, Sèrie VG: 21 (1600-01); 26 (160203); 33 (1605-06); 37, 38, 212 (1608-09); 214 (1611-12); 58 (1614-15); 70 (1620-21); 79 (1623-24). ACA, Generalitat, Sèrie G, 8: 2 (1626-27); 1 (1629-30\&1632-33); 5 (1638-39\&1641-42); 4 (1644-45\&1647-48\&1650-51); 3 (1654-55); 6 (1656-57); 7 (1659-60\&1662-63); 8 (1665-66); 9 (1668-69\&1671-72); 10 (1674-75\&1677-78\&1680-81); 11 (1683-84); 12 (1686-87); 13 (1689-90\&1692-93); 14 (1695-96\&1698-99); 15 (1701-02); 16 (1704-05); 17 (1707-08); 18 (1710-11).

49 Joan Felipó fou finalment substituït per un tal Sebastià Miquel, nomenat pel diputat local del trienni de 1629-1632, Miquel Soler. ACA, Generalitat, Sèrie G, 8, 1, $2^{\mathrm{a}}$ part, ff. 14v-15v. Tanmateix, el nomenament del nou oficial no es traduí en la desaparició de les irregularitats. En aquest sentit, sabem que a 14 d'octubre de 1633 els diputats i oïdors de comptes de la Diputació del General escrigueren al diputat local de Vilafranca de Conflent per exigir-li que advertís a l'assessor, l'advocat fiscal i el procurador fiscal conflentins -els noms dels quals no s'esmenten- que a partir d'aquell moment els processos instats davant la seu del General a Vilafranca ho fossin seguint allò disposat en les Constitucions Catalanes i la pràctica, ús i estil de la Generalitat. Concretament, l'escrit reclamava que l'assessor, l'advocat fiscal i el procurador fiscal participessin col legiadament en tots els processos, declaracions i sentències instats davant la Diputació local de Vilafranca de Conflent, per evitar les irregularitats detectades pels visitadors de 1632-1633. ACA, Generalitat, Sèrie N, 849, ff. 60v-62r. 
Ricard Torra. Territori i relacions institucionals a la Catalunya del Sis-cents. Tres estudis de cas a partir dels processos de la Visita del General de Catalunya

\section{1 «A fe que los abaxarem la sivada als visitadors, que molt se volen engroxir». Dificultats econòmiques i tensions institucionals en el marc de la Visita de 1654-1655}

D'ençà uns anys, per a la historiografia catalana d'època moderna és un fet àmpliament acceptat que el «retorn» del Principat a l'obediència de Felip IV escenificat a finals del 1652 suposà un abans i un després per les institucions catalanes. En aquest sentit, les reformes en matèria d'insaculacions introduïdes tant al Consell de Cent Barceloní com a la Diputació del General els anys 1653 i 1654, respectivament, no foren sinó el preludi d'una època -la segona meitat del segle XVII- marcada per la lluita de la classe dirigent catalana amb l'objectiu de recuperar l'estatus constitucional -l'autogovern, hom ha dit (Simon 2011) - perdut l'any 1652. Així, autors com ara Fernando Sánchez Marcos (1983), Josep Maria Torras i Ribé (1993) o Eva Serra (1997) han demostrat a bastament l'envergadura de les reformes introduïdes per la Monarquia Hispànica al Principat durant la segona meitat del segle XVII, mentre que només Xavier Gil (2001) sembla haver matisat aquesta qüestió. ${ }^{50}$

Molt probablement on més es notà la magnitud de les reformes introduïdes per la monarquia fou en l'àmbit jurisdiccional de la Generalitat, especialment pel que fa a les dues principals institucions que el componien, això és, la Diputació del General de Catalunya i la Visita del General de Catalunya. En aquest sentit, pel que fa a la Diputació més enllà del control del sistema insaculatori, Eva Serra (2011b: 206-208) n'ha evidenciat l'afebliment dels ingressos, que si a principis del segle XVII hom calcula a l'entorn de les 170.000 lliures barcelonines anuals, a partir de 1652 semblen haver patit una davallada prou important, situant-se l'any 1702 en unes 123.000 lliures barcelonines a l'any. La institució, que entre 1652 i 1700 havia aconseguit eixugar llur deute en prop de 400.000 lliures, a finals de segle encara n'arrossegava un de més de dos milions i mig, fruit dels emprèstits contrets en el marc de la Guerra dels Segadors (1640-1652) i del context polític tal vegada advers a partir de 1652.

De fet, les dificultats econòmiques de la hisenda del General semblen haver arribat al seu punt àlgid en els moments immediatament posteriors al retorn de 1652. A la suara esmentada crisi del deute públic derivada dels esforços de guerra contra Felip IV, caldria afegir-hi el segrest efectuat per la Capitania General d'importants ingressos per la Diputació, com ara la Nova Ampra, així com també la pèrdua efectiva del control sobre els Comtats Catalans, que acabà de segellar-se mitjançant el Tractat dels Pirineus l'any 1659. ${ }^{51}$

50 En aquest sentit, Gil manté que més que d'un canvi constitucional o de la fi del «pactisme», a partir del «retorn» de 1652 el que caldria és parlar de l'existència d'una mutació pel que fa a les dinàmiques pactistes/forals. Tanmateix, llur proposta, tal vegada suggeridora, es basa exclusivament en bibliografia secundària, sense tenir en compte la quantitat notable de documentació conservada en diversos arxius que apuntaria, justament, tot el contrari. (GIL 2001: 115). Sense ànim de ser exhaustius: 1- La «mercè de concessió» de les Constitucions Catalanes (Dietaris de la Generalitat de Catalunya, vol. VI, p. 1223); 2- El fet que des de 1652 la Diputació del General registrés en dos volums la legislació reial «aplicable a» la jurisdicció del General, fet sense precedents (ACA, Generalitat, Sèrie G, 224, 27 i 28); 3- Les reformes introduïdes per la monarquia a la Visita del General, malgrat el fet que es tractava d'una parcel la jurisdiccional que li era totalment aliena (Torra, 2014b: 124-128).

51 Sobre les conseqüències del Tractat dels Pirineus i les disputes que mantingueren els exèrcits hispànics i francesos

SCRIPTA, Revista internacional de literatura i cultura medieval i moderna, núm. 13 / juny 2019 / pp. 212 - 242

ISSN: 2340-4841 · doi:10.7203/SCRIPTA.13.15482 
Ricard Torra. Territori i relacions institucionals a la Catalunya del Sis-cents. Tres estudis de cas a partir dels processos de la Visita del General de Catalunya

És en aquest context advers que cal situar els processos de les querelles número 30 i 42 de la Visita del General de 1656-1657. En aquestes, s'acusà als diputats i oïdors de comptes del trienni de 16541656 - excepcionalment i de resultes del desenllaç de la Guerra dels Segadors i de les modificacions introduïdes per Felip IV en el sistema d'insaculació el trienni de 1650 s'havia allargat uns mesos més enllà del mes de juliol de 1653 quan, en teoria, hauria d'haver finalitzat- d'haver-se oposat obstinadament a les demandes de diners fetes pels visitadors de $1654-1655^{52}$ El Capítol 1 del Redreç de 1599 havia atorgat una autonomia financera gens menyspreable a la Visita. Si bé els salaris dels oficials de la institució havien estat clarament delimitats, el propi capítol determinava que els diputats i oïdors de comptes del General havien de «girar de les pecúnies del General al regent los comptes, las quantitats que per fer-se dita Visita ordenaran dits visitadors o la major part d'ells». ${ }^{53}$ Aquest coixí econòmic permeté als successius consistoris de la Visita de les primeres dècades del segle XVII desenvolupar la institució en diversos àmbits: en primer lloc, permeté la celebració de les visites foranes, estudiades per Eva Serra (2011a), les quals es caracteritzaren per la seva minuciositat i evolució constant; segonament, permeté l'assentament i expansió del consistori de la Visita dins del marc institucional de la Catalunya de la primera meitat del segle XVII; tercerament, la capacitat econòmica de la institució també li permeté afrontar els diversos embats polítics que, derivats de l'auge de la institució dins del suara mencionat marc institucional català de la primera meitat del segle XVII, s'anaren succeint (Torra 2016); en quart lloc, fruit en bona part d'aquesta bonança econòmica, la Visita publicà diversos impresos, tres dedicats als oficials del General i dos dedicats al propi procediment de la Visita. En definitiva, la seguretat econòmica permeté que els agents fiscalitzadors centressin els seus esforços en la tasques que les Corts de 1599 els havien encomanat -això és, la supervisió de la Generalitat-.

Tanmateix, aquesta situació començà a virar amb l'arribada de la Guerra dels Segadors. En aquest sentit, les necessitats econòmiques fruit de l'enfrontament amb Felip IV feren que la Junta General de Braços decidís limitar les despeses de la Visita celebrada entre 1641 i 1642 a un màxim de 6.500 lliures barcelonines. ${ }^{54}$ Encara que la situació es revertí de forma progressiva durant les següents fiscalitzacions, un cop finalitzat el conflicte bèl lic i coincidint amb el «retorn» del Principat a l'obediència de la Monarquia Hispànica, la Diputació del General intentà limitar el poder d'actuació de la Visita en els àmbits polític, jurídic i econòmic. Així, durant la Visita celebrada els anys 1654 i 1655 els agents fiscalitzadors tingueren nombroses dificultats per aconseguir que els diputats els entreguessin les quantitats de diner necessàries per dur a terme la seva feina. La manca de

els anys subsegüents amb l'objectiu d'establir una nova frontera militar vegeu Espino (2014: 54-79).

52 ACA, Generalitat, Sèrie G, 8, 6, ff. 46r-47v.

53 Capitols per lo redrec... (1603), p. 8.

54 ACA, Generalitat, Sèrie G, 6, 6, 1, ff. 12v-13r i DGC, vol. V, p. 1198. Segons els comptes de la Visita de 1641-1642 elaborats pel regent els comptes del General, s'acabaren entregant als visitadors un total de 7.405 lliures barcelonines. ACA, Generalitat, Sèrie G, 36, 4.

SCRIPTA, Revista internacional de literatura i cultura medieval i moderna, núm. 13 / juny 2019 / pp. 212 - 242 ISSN: $2340-4841 \cdot$ doi:10.7203/SCRIPTA.13.15482 
col laboració dels dirigents de la Diputació i els consegüents intents dels visitadors per aconseguir els diners mitjançant manaments dirigits als principals oficials pecuniaris del General, portà les relacions entre ambdós consistoris al llindar del trencament. En efecte: entre el 30 d'abril i el 10 de desembre de 1654, diputats i oïdors de comptes d'una banda, i visitadors d'altra banda, intercanviaren nombroses ambaixades (i no menys retrets) per aquesta qüestió. ${ }^{55}$ Així, els agents fiscalitzadors es queixaven del fet que la manca de numerari estava dificultant enormement la seva feina -arribant a l'extrem de deixar inacabats alguns processos ${ }^{56}$ i denunciaven la interpretació «tant sinistre y mala del dit Capítol 1 del nou Redrés del General de las Corts del any 1599» feta pels diputats, «contrària al que fins assí s és observat». ${ }^{57}$ Contràriament, els diputats i ö̈dors de comptes asseguraven que feien el que podien, tot i que a mitjans del mes de maig de 1654 encara devien els salaris dels oficials de la terça corresponent als mesos de gener, febrer i març de 1654, les estrenes per l'habilitació i extracció dels diputats i visitadors i en motiu de la festivitat de Sant Jordi, així com també les terces dels salaris dels membres de la Reial Audiència de Catalunya. A més a més, encara calia sumar-hi la migradesa dels ingressos provinents de les generalitats i la impossibilitat d'arrendar les bolles de Perpinyà, Girona, Manresa, Lleida, Berga, Bagà, Ripoll i Sant Joan de les Abadesses, ja que es trobaven ocupades pels francesos. ${ }^{58}$ Tot plegat comportà que quan a mitjans d'octubre de 1654 els visitadors insistiren de nou en demanar diners per dur a terme la seva tasca-segons sembla els diputats no havien complert les condicions d'un pacte establert a principis del mes de juny del mateix any que havia de garantir el finançament de la institució fiscalitzadora i d'un total de 4.000 lliures pressupostades, només se n'havien entregat 2.700- els diputats els responguessin que degut a les dificultats econòmiques, haurien de conformar-se amb 300 lliures barcelonines i que

$$
\begin{aligned}
& \text { si no que las dexassen, que ja tenien rebut cinc mil y tres centes lliures y no eran sinó a mitja } \\
& \text { Visita. y que què pretenien fer ab tant gastar, y que si pensaven exos senyors que havien de } \\
& \text { menjar més que ells anaven enganyats. Y que altres visitas se havien fet ab set milia lliures de } \\
& \text { gasto, que no pensaven donar-los-ne més. }
\end{aligned}
$$

Les explicacions dels diputats sembla ser que no convenceren pas als visitadors, que entre els dies 29 i 30 d'octubre presentaren manaments a diversos oficials de la Diputació amb l'objectiu

55 L'inici del contenciós a ACA, Generalitat, Sèrie G, 6, 8, ff. 11v-12r. La majoria de notícies sobre aquest afer foren esborrades dels registres d'ambdues institucions. De fet, si podem resseguir-lo fil per randa és gràcies al fet que en el marc de la querella núm. 40 de la Visita de 1656-1657 es copiaren les notícies esborrades del dietari de la Visita del General. Cfr. ACA, Generalitat, Sèrie VG, 132, camisa 25, ff. 5r-36r.

56 Ibídem, ff. 18r-19v.

57 Ibídem, ff. 10v-12r.

58 Ibídem, ff. 9v-10r.

59 Ibídem, ff. 13r-14r.

SCRIPTA, Revista internacional de literatura i cultura medieval i moderna, núm. 13 / juny 2019 / pp. 212 - 242 ISSN: 2340-4841 · doi:10.7203/SCRIPTA.13.15482 
de garantir llurs demandes de numerari. ${ }^{60}$ Tot plegat enfurismà als dirigents de la Diputació del General, que recordaren als visitadors que llurs prerrogatives només preveien «sindicar lo fet del trienni passat, y que encara que en dit Capítol primer estiga imposada obligatió als officials del General de que assistesquen als molt illustres visitadors quant sie menester [...] és en quant diu respecte al efecte de la Visita y executió de aquella, no emperò és en quant conté saltem a la functió de sos officis per diversos Capítols de Cort disposada». ${ }^{61}$ Per tot plegat, demanaven als visitadors que anul lessin els manaments «com a turbatius de la líbera administratió y exactió de las pecúnies y drets de la Generalitat», així com els esborressin dels registres i dietari de la Visita del General. ${ }^{62}$

La situació, lluny de calmar-se anà in crescendo a mesura que avançà el mes de novembre. De fet, a primers de desembre de 1654 les posicions estaven més enrocades que mai: una escriptura dels visitadors presentada al consistori dels diputats i oïdors de comptes el primer dia d'aquest mes no fou acceptada al legant que contenia passatges ofensius contra la institució; els dirigents de la Diputació demanaren que algunes de les afirmacions contingudes en l'escrit -on se'ls acusava de no voler emparar les demandes fetes pels visitadors malgrat allò disposat pel Capítol 1 del Redreç de 1599- fossin esborrades i, de fet, es negaren a acceptar-la fins i tot quant els porters de la Visita els l'entregaren als seus domicilis particulars. ${ }^{63} \mathrm{El}$ següent jorn -2 de desembre de 1654- els diputats intentaren acostar posicions oferint avançar unes 2.000 lliures que havien de sumar-se a les 6.000 que teòricament ja havia rebut la Visita. ${ }^{64}$ Tanmateix, els visitadors no es donaren per satisfets, bo i pretenent que els diputats els reconeguessin la potestat que tenien de demanar tot allò que consideressin necessari per tirar endavant la seva feina. Per tot plegat, el dia 5 de desembre decidiren publicar diversos manaments contra els diputats i oïdors de comptes i i diversos oficials de la Diputació amb l'objectiu d'impedir que els primers poguessin deliberar qualssevol pagaments, ${ }^{65}$ decisió que fou resposta pels dirigents de la Diputació amb la captura i empresonament dels porters de la Visita que els havien entregat els manaments. ${ }^{66}$ Arribats a aquest

60 Concretament, els visitadors cursaren manaments contra el regent els comptes i el racional amb l'objectiu d'obtenir els comptes de la Diputació entre els mesos d'agost i octubre de 1654; contra l'escrivà major de la Diputació perquè no anotés deliberacions dels diputats en matèria de pagaments fins que no s'hagués entregat tot allò reclamat per la Visita del General; finalment, contra Pere Farell, receptor de la taula de Barcelona, perquè lliurés tots els diners que anés rebent al regent els comptes, amb l'objectiu que aquest darrer pagués els diners reclamats pels agents fiscalitzadors. Ibídem, f. 19v.

61 Ibídem, ff. 21r-21v.

62 Ibídem, ff. 21v-22r.

63 Ibídem, ff. $24 \mathrm{r}-27 \mathrm{v}$.

64 Ibídem, ff. 28r-28v. L’ambaixada que els diputats trameteren als agents fiscalitzadors estigué liderada per Ramon de Copons i Josep de Navel.

65 Ibídem, ff. 30v-31r.

66 Ibídem, ff. 32v-34r.

SCRIPTA, Revista internacional de literatura i cultura medieval i moderna, núm. 13 / juny 2019 / pp. 212 - 242 ISSN: 2340-4841 · doi:10.7203/SCRIPTA.13.15482 
Ricard Torra. Territori i relacions institucionals a la Catalunya del Sis-cents. Tres estudis de cas a partir dels processos de la Visita del General de Catalunya

punt, tot sembla indicar que visitadors i diputats optaren finalment per rebaixar el conflicte: tot i que segons una entrada del dietari de la Visita datada a 10 de gener de 1655 la fiscalització encara estava aturada «per ocasió de la contentió y hagué ab los molt il lustres senyors deputats», ${ }^{67}$ gràcies a l'escrit de defensa que els diputats i oïdors de comptes presentaren en el marc de la querella núm. 42 sabem que ambdós consistoris finalment acordaren esborrar dels registres documentals de les dues institucions qualssevol referències a l'enfrontament. ${ }^{68} \mathrm{I}$ encara, pel que fa al finançament de la Visita, gràcies al registre de comptes de la institució elaborat pel regent els comptes del General sabem que els agents fiscalitzadors acabaren rebent un total 5.300 lliures barcelonines, quantitat tal vegada discreta, sobretot tenint en compte que la Visita que fins llavors havia rebut menys doblers -la de 1641-1642- n'havia rebut prop de 7.500. ${ }^{69}$

Les conseqüències de l'enfrontament entre consistoris i l'escassedat monetària patida per la Visita del General de 1654-1655 tingueren repercussió més enllà del trienni de 1654-1656. En aquest sentit, pel que fa a les limitacions econòmiques -que tal i com havien denunciat els propis visitadors els havien impedit dur a terme correctament la seva tasca- una bona mostra en són les queixes del diputat local de Girona durant la Visita de 1656-1657. En efecte, requerit pels visitadors amb l'objectiu que dugués a terme diferents gestions relacionades amb la fiscalització dins el territori sota la seva jurisdicció, els respongué que durant la inspecció de 1654-1655 havia avançat 33 lliures «de ma bossa» per poder publicar les crides de la Visita a la col lecta de Girona, diners que «quan aquí instí per la cobransa, me respongueren a la Visita que los senyors deputats me pagarian, y quan demaní als senyors deputats me digueren me pagarian los senyors visitadors, axí que ni de hu ni altre poguí cobrar y avuy [encara] se'm deu». Amb tot, el diputat local de Girona estava disposat a avançar de nou els diners necessaris per fer publicar les crides de la Visita de 1656-1657, sempre i quan els visitadors li'n garantissin el reemborsament -juntament amb els de la inspecció anterior-, qüestió que els agents fiscalitzadors s'afanyaren a confirmar. ${ }^{70}$

\subsection{El desenllaç de les tibantors. La Visita de 1656-1657}

Pel que fa a l'enfrontament entre els consistoris de la Visita del General i la Diputació del General, tot plegat s'acabà dirimint com hem dit anteriorment en el marc de les querelles número 30 i 42

67 ACA, Generalitat, Sèrie G, 6, 8, f. 233v.

68 ACA, Generalitat, Sèrie VG, 132, camisa 25, f. 1v, escrit de la defensa.

69 ACA, Generalitat, Sèrie G, 36, 4, comptes de les visites de 1641-1642 i 1654-1655, respectivament.

70 ACA, Generalitat, Sèrie G, 6, 9, f. 20r-21r. Des del nostre punt de vista, l'actitud del diputat local de Girona és prou il lustrativa del compromís cívic que diversos oficials de la Diputació semblen haver demostrat amb la institució; un compromís que, d'altra banda, contradiu en bona mesura afirmacions fetes des de certs àmbits historiogràfics, els quals haurien assegurat que «els catalans del segle XVI i XVII no haurien entès el poder en termes de servei, sinó de benefici». (Palos 1994: 309).

SCRIPTA, Revista internacional de literatura i cultura medieval i moderna, núm. 13 / juny 2019 / pp. 212 - 242 ISSN: $2340-4841 \cdot$ doi:10.7203/SCRIPTA.13.15482 
Ricard Torra. Territori i relacions institucionals a la Catalunya del Sis-cents. Tres estudis de cas a partir dels processos de la Visita del General de Catalunya

de la Visita de 1656-1657, els processos de les quals en bona mesura es complementen. Com hem vist, el procés de la querella número 42 ens permet reconstruir en part el relat «oficial» de les discrepàncies sorgides entre ambdós consistoris a partir de les entrades retirades del dietari de la Visita del General. Per la seva banda, el procés de la querella número 30 permet endinsar-nos en les interioritats d'aquest contenciós, ja que tant els interrogatoris com les proves aportades per l'acusació són riquíssims en detalls. Així, un primer element a destacar no seria altre que el registre de rebudes del regent els comptes del General, documentació que els visitadors de 16541655 ja intentaren obtenir i que els diputats i oïdors de comptes del trienni de 1654-1656 «se n'aportaren en llurs casas [...] per a què nosaltres no poguéssem vèurer y saber si tenian diner». ${ }^{71}$ Segons aquesta documentació -elaborada pels calculadors de la institució fiscalitzadora a partir dels treballs que havien realitzat a l'arxiu del regent els comptes-, entre el 17 d'abril i el 9 d'octubre de 1654 la Diputació del General havia ingressat un total de 21.042 lliures, 13 sous i 9 diners, quantitat que segons l'acusació hauria d'haver permès als diputats satisfer les demandes monetàries dels visitadors. ${ }^{72}$ De fet, dels testimonis presentats per l'acusació se'n desprèn que els dirigents de la Diputació entre 1654-1656 feren tot el possible per impedir que la Visita tingués un finançament adient a les seves necessitats. A tall d'exemple, segons Joan Baptista d'Avinyó -visitador militar de 1654-1655- veient el consistori de la Visita que els de la Diputació no volien entregar-los els doblers demanats optaren per promulgar manaments contra aquests darrers, fet que propicià el trencament de les relacions entre ambdós consistoris escenificat quan els ambaixadors de la Visita -l'escrivà major Miquel Serra, l'advocat fiscal Ramon Ripoll i el procurador fiscal Francesc Taquí ${ }^{73}$ hagueren d'abandonar el consistori de la Diputació després d'escoltar «que són donas los visitadors! Que sempre han de estar demanant!» o «A fe que los abaxarem la sivada als visitadors, que molt se volen engroxir!». ${ }^{74}$

Com era d'esperar, els interrogatoris dirigits contra els acusats en el marc de la querella número 30 oferiren una visió totalment diferent dels fets. Així, Ignasi de Ripoll, oïdor eclesiàstic del trienni de 1654-1656 si bé no negà les reiterades peticions monetàries fetes pels visitadors, assegurà que

71 ACA, Generalitat, Sèrie VG, 132, procés de la querella número 30, s/f. Declaració de Jacint Andreu, visitador del braç reial de 1654-1655.

72 Ibídem, s/f, «Comensa dit llibre intitulat de rebudes en fol -1- i acaba en fol -6-».

73 Ibídem, s/f, Declaració de Joan Baptista d'Avinyó, visitador del braç militar de 1654-1655, datada a 6-X-1656 i DGC, vol. VI, pp. 588-597.

74 ACA, Generalitat, Sèrie VG, 132, procés de la querella número 30, s/f. Declaració de Joan Baptista d’Avinyó, visitador del braç militar de 1654-1655, datada a 6-X-1656. La declaració d’Avinyó fou confirmada successivament per Miquel Serra, escrivà major de la Visita de 1654-1655 (9-X-1656); Pau de Planella, visitador del braç militar de $1654-$ 1655 (10-X-1656); Francesc Taquí, procurador fiscal de la Visita de 1654-1655 (10-X-1656); Jacint Andreu, visitador del braç reial de 1654-1655 (17-X-1656); i Rafel Hexarch, escrivent ordinari de la Visita de 1654-1655 (21-X-1656). Contràriament, les declaracions de Miquel Joan Osona, visitador del braç eclesiàstic de 1654-1655 (4-XII-1656) i Bernat de Lentisclar, ajudant de l'escrivà major de la Visita de 1654-1655 (13-XII-1656), si bé no s'oposaven a les dels seus companys, eren tal vegada menys bel ligerants amb els dirigents de la Diputació.

SCRIPTA, Revista internacional de literatura i cultura medieval i moderna, núm. 13 / juny 2019 / pp. 212 - 242 ISSN: 2340-4841 · doi:10.7203/SCRIPTA.13.15482 
Ricard Torra. Territori i relacions institucionals a la Catalunya del Sis-cents. Tres estudis de cas a partir dels processos de la Visita del General de Catalunya

diputats i oïdors de comptes havien fet el que bonament havien pogut atenent a les circumstàncies tal vegada adverses que travessava la hisenda de la Generalitat. ${ }^{75}$ De manera semblant respongué a les inquisicions dels visitadors Pere de Padellàs, diputat militar, qui afegí que «no entench que per part del consistori de deputats y oÿdors y hagués culpa en la tardansa de dita Visita». ${ }^{76}$ I encara, Joan Gabriel i Agustí Pinyana -oïdor i diputat reials, respectivament- també semblen coincidir amb l'opinió dels seus companys de consistori; de fet, segons Pinyana l'actuació dels dirigents de la Diputació del General fou perfectament adequada al dret vigent i «ya té dit que acudiren ab molta puntualitat y conformitat de dits senyors visitadors, de què quedaren molt gustosos aquells». ${ }^{77}$

No ens hauria d'estranyar, doncs, que la defensa presentada pels acusats i signada pels doctors en drets Aleix Tristany i (Joan Baptista?) Pastor fos certament bel ligerant. ${ }^{78}$ Els vint-i-nou capítols de l'escrit pel qual els acusats exigien la retirada de la querella, es poden resumir en cinc grans idees: en primer lloc, denunciaven que en iniciar el seu mandat a la Diputació els anteriors dirigents els havien entregat buides les arques de la institució, així com també havien deixat pendents diversos pagaments, fet que havia suposat un contratemps notable pel consistori de 1654-1656, que ni tan sols amb uns ingressos de més de 21.000 lliures entre els mesos d'abril i octubre de 1654 havia sigut capaç de redreçar la hisenda de la institució (capítols 1 a 7); segonament, asseguraven que, tot i la situació econòmicament adversa, s'havia fet tot el possible per satisfer les quantitats de doblers demanades pels visitadors, fins $\mathrm{i}$ tot deixant de pagar les nòmines dels oficials de la Diputació (capítols 8 a 10); malgrat «las calamitats del temps y falta de monedas que aleshores corria», els esforços fets pels diputats i oïdors de comptes intentaven demostrar que lluny de poderlos acusar de negligents, compliren amb allò disposat en el Capítol 1 del Redreç de 1599 (capítols 11 i 12); en quart lloc, la defensa recordava que de mutu acord, diputats i visitadors acordaren esborrar dels registres d'ambdues institucions les polèmiques viscudes en motiu del finançament de la Visita del General (capítols 13 a 15); finalment, en cinquè i darrer terme, l'escrit de la defensa intentava evidenciar que totes les proves aportades pel procurador fiscal estaven mal fonamentades, especialment pel que fa a les declaracions dels dirigents de la Visita del General de 1654-1655 (capítols 16 a 25$).{ }^{79}$

75 ACA, Generalitat, Sèrie VG, 132, procés de la querella número 30, s/f. Declaració d'Ignasi de Ripoll, oïdor eclesiàstic del trienni de 1654-1656, datada a 7-XII-1656.

76 Ibídem. Declaració de Pere de Padellàs, diputat militar del trienni de 1654-1656, datada a 11-XII-1656.

77 Ibídem. Declaració d'Agustí Pinyana, diputat reial del trienni de 1654-1656, datada a 13-XII-1656; declaració de Joan Gabriel, oïdor reial del trienni de 1654-1656, datada a 15-XII-1656.

78 Ibídem. Defensa presentada pels acusats a 19-I-1657.

79 En el cas de les declaracions aportades com a prova acusatòria pel procurador fiscal de la Visita, l'escrit de la defensa en criticà molt especialment el fet que s'acusés als diputats i oïdors de comptes d'ésser els causants del fet de no haver pogut executar diverses sentències de la Visita perquè la contenció amb els visitadors havia endarrerit l'execució i, durant aquest temps, els francesos havien ocupat diversos territoris catalans. Tanmateix, segons la defensa els territoris ocupats pels exèrcits francesos -Comtat de Cerdanya, la Seu d’Urgell, Camprodon, Solsona, Castelló d'Empúries i

SCRIPTA, Revista internacional de literatura i cultura medieval i moderna, núm. 13 / juny 2019 / pp. 212 - 242 ISSN: $2340-4841 \cdot$ doi:10.7203/SCRIPTA.13.15482 
Ricard Torra. Territori i relacions institucionals a la Catalunya del Sis-cents. Tres estudis de cas a partir dels processos de la Visita del General de Catalunya

Amb l'objectiu de solidificar encara més llurs posicions, els acusats presentaren una bateria de testimonis favorables a la seva defensa. Així, davant dels visitadors desfilaren Gabriel Llorells, notari causídic, Gispert Amat i Desbosc, abat de Sant Cugat del Vallès, Joan Francesc Ferrer, mercader de Barcelona, Lluís de Valencià, doctor en drets i oïdor militar del trienni de 1650-1654, Ramon Par, assessor del General, Onofre Delfau, burgès de Perpinyà, Jeroni Major i Sala, sobrecollidor del General, Miquel Joan Osona, visitador del braç eclesiàstic de 1654-1655, Joan Baptista Arrufat, assessor del General, Miquel Serra, escrivà major de la Visita de 1654-1655 i, finalment, Bernat de Lentisclar, ajudant de l'escrivà major de la Visita de 1654-1655. ${ }^{80}$ Tanmateix, l'esforç fet pels acusats no aconseguí convèncer als visitadors de 1656-1657. Així, en el marc de la sentència de la querella número 30, considerant provat que els dirigents de la Diputació del General durant el trienni de 1654-1656 havien comès una clara contrafacció del Capítol 1 del Redreç de 1599, els condemnaren a pagar una multa conjunta de quatre-centes lliures barcelonines, si bé n'exoneraren a Ignasi de Ripoll, oïdor militar, en considerar que havia protestat contra l'actuació de llurs companys de consistori. ${ }^{81}$ Pel que fa a la sentència de la querella número 42 , atenent al fet que «consta haver dits deputats y oydors no sols negat lo degut favor y ajuda a dit molt Illustre consistori de la Visita prop passada, però encara formiter ésser-se opposats a la jurisdictió de aquella [...] ab molt gran menyspreu de dit molt Illustre consistori», els visitadors condemnaren als dirigents de la Diputació del General del trienni de 1654-1656 a pagar una multa de vuit-centes lliures barcelonines, absolentne emperò a Ignasi de Ripoll -pel mateix motiu que la sentència de la querella número 30-i a Isabel de Padellàs, vídua del diputat militar Pere de Padellàs. ${ }^{82}$

Val a dir que l'acció de la Visita del General no s'aturava pas un cop promulgades les sentències. En el cas que ens ocupa -això és, el de les querelles número 30 i 42 de la Visita de 1656-1657- els sentenciats intentaren capgirar la decisió dels agents fiscalitzadors en diverses ocasions. Així, el 19 de maig de 1657 presentaren una suplicació davant el consistori de la Visita en la que demanaven la seva absolució tot reiterant que el fet de no haver assistit als visitadors de 1654-1655 fou degut a les dificultats econòmiques que patia la hisenda de la Generalitat. ${ }^{83}$ L'endemà mateix, Pau Vinyes, que havia exercit com a oïdor militar durant

Cadaqués-, ho havien estat ja durant la instrucció de les causes coincidint amb l'ofensiva gal la de l'any 1654 i, per tant, molt abans del moment de l'execució de les sentències, això és, a mitjans de l'any 1655. Val a dir que l'explicació de la defensa pel que fa a l'ofensiva francesa coincideix plenament amb l'aportada recentment per Antonio Espino (2014: 41).

80 ACA, Generalitat, Sèrie VG, 132, procés de la querella número 30, s/f. Declaracions de Gabriel Llorells (15-II1657); Gispert Amat i Desbosc (16-II-1657); Joan Francesc Ferrer (17-II-1657); Lluís de Valencià (17-II-1657); Ramon Par (17-II-1657); Onofre Delfau (17-II-1657); Jeroni Major i Sala (19-II-1657); Miquel Joan Osona (19-II-1657); Joan Baptista Arrufat (19-II-1657); Miquel Serra (20-II-1657); Bernat de Lentisclar (21-II-1657).

81 ACA, Generalitat, Sèrie G, 8, 6, ff. 44r-46r.

82 Ibídem, ff. 46r-47v.

83 Ibídem, ff. 122r-122v.

SCRIPTA, Revista internacional de literatura i cultura medieval i moderna, núm. 13 / juny 2019 / pp. 212 - 242 ISSN: 2340-4841 · doi:10.7203/SCRIPTA.13.15482 
Ricard Torra. Territori i relacions institucionals a la Catalunya del Sis-cents. Tres estudis de cas a partir dels processos de la Visita del General de Catalunya

el trienni fiscalitzat presentà una altra suplicació assegurant que, com Ignasi de Ripoll, ell tampoc havia participat en les decisions contràries als interessos de la Visita del General, estratègia que poc després calcaren Agustí Pinyana i Joan Gabriel. ${ }^{84}$ Aquestes gestions dutes a terme per part dels sentenciats solien tenir com a objectiu la rebaixa de la pena imposada pels visitadors en el moment que aquests publicaven el decret d'execució de les sentències. I tot pareix indicar que se sortiren, en part, amb la seva: en aquest sentit, Pau Vinyes pogué escapolir-se del dictamen final previst en el decret d'execució, mentre que pel que fa a la resta de consistorials, la pena en el cas de la querella número 30 es reduí a un total de 150 lliures barcelonines -50 lliures Francesc Pejoan, 50 lliures Pere de Padellàs i 50 lliures Joan Gabriel- i la de la querella número 42 es rebaixà fins a 300 lliures barcelonines -125 lliures Francesc Pejoan, 125 lliures Agustí Pinyana i 50 lliures Joan Gabriel-. Publicats els decrets d'execució, els condemnats, ara ja en ferm, foren anotats com a deutors als Llibres de Vàlues del General del trienni de 1656-1659. ${ }^{85}$

Arribats a aquest punt els deutors tenien, principalment, dues opcions: bé satisfer el deute contret amb la hisenda de la Generalitat i recuperar els drets polítics perduts -ser deutor era incompatible amb l'exercici dels principals càrrecs de la institució-, bé no satisfer-lo tot esperant que tard o d'hora l'exactor del General els executés en béns per recuperar allò que devien. ${ }^{86}$ Tanmateix, a partir de 1652 es començà a desenvolupar la pràctica de presentar recursos contra les sentències de la Visita davant la jurisdicció del rei, concretament, davant la Reial Audiència de Catalunya. Això permetia als recusants paralitzar el procés d'execució de les sentències i, per tant, també el fet d'ésser executats com a deutors de la Generalitat, qüestió aquesta que passava a estar condicionada pel veredicte emès per la magistratura reial. I, de fet, el que realment succeïa és que tot plegat quedava suspès de manera permanent, ja que un cop els condemnats instaven un procés davant el tribunal reial, la Generalitat representada bé pel procurador fiscal de la Visita, bé pel procurador fiscal de la Diputació quan la primera no estava activa, declinaven pledejar davant una jurisdicció que consideraven aliena. Precisament, aquest darrer extrem, el del recurs davant la Reial Audiència, és el que empraren els condemnats en el marc de les querelles número 30 i 42 de la Visita de 1656-

\footnotetext{
84 Ibídem, ff. 160r-162v i 174r.
}

85 ACA, Generalitat, Sèrie G, 85, 34, ff. 645-646. Els Llibres de Vàlues del General eren el registre on el racional de la Diputació del General anotava tots els deutors de la institució perquè, cas que no paguessin, l'exactor del General pogués executar-los en llurs béns.

86 A tall d'exemple, en el marc de la sentència de la querella número 7 de la Visita de 1656-1657, diputats i oïdors de comptes foren condemnats a pagar individualment 53 lliures, 18 sous i 4 diners en motiu d'haver-se deliberat pagaments en plata en comptes d'ardits en celebrar-se les insaculacions del mes de juliol de 1656. ACA, Generalitat, Sèrie G, 8, 6, ff. 4r-6r. Publicats els decrets d'execució, tots ells foren anotats com a deutors en el Llibre de Vàlues del General: a partir d'aquest moment, mentre Ignasi de Ripoll, Pau Vinyes i Joan Gabriel optaren per satisfer el deute, Isabel de Padellàs -vídua de Pere de Padellàs- només ho feu parcialment i Agustí Pinyana optà per no satisfer-lo. ACA, Generalitat, Sèrie G, 85, 34, ff. 655-656. 
Ricard Torra. Territori i relacions institucionals a la Catalunya del Sis-cents. Tres estudis de cas a partir dels processos de la Visita del General de Catalunya

1657. ${ }^{87}$ I pel que sembla, tots ells aconseguiren estabilitzar la seva condició de deutors, ja que a 1 d'agost de 1659 -data de l'inici d'un nou trienni a la Diputació- encara no havien satisfet el deute. ${ }^{88}$

\section{Conclusions}

Com hem tingut l'oportunitat de veure a través dels casos exposats en el nostre estudi, els processos i sentències de la Visita del General de Catalunya resulten una font d'un potencial enorme per estudiar tant l'articulació territorial com la pràctica institucional de la Diputació del General de Catalunya durant el segle XVII. En aquest sentit, l'anàlisi de les querelles número 121 i 123 de la Visita del General celebrada entre 1629 i 1630 ens ha permès constatar les dificultats viscudes per la Diputació del General en el seu procés d'expansió territorial, concretament pel que fa a les terres frontereres amb el Regne de França. Aquesta situació l'hem poguda entreveure des d'almenys tres àmbits: 1- primerament, a partir de les queixes que els propis oficials territorials de la Diputació plantejaven a instàncies superiors -fos el consistori de Barcelona, fossin els visitadors- arran de les dificultats que tenien per veure reconeguda llur autoritat en aquelles contrades (Pérez Latre 2004: 147-150); 2- En segon lloc, fent evident l'existència d'una clara contestació vers el pagament de les imposicions de la Generalitat (Pérez Latre 2004: 140-145; Duran 2003: 32), situació tal vegada complexa i molt ben estudiada per Cárceles de Gea (2000) pel cas castellà; 3- tercerament, demostrant com els oficials territorials de la Diputació del General atenent a un context tal vegada advers, però també a interessos personals -com molt bé ha apuntat Eva Serra (2011a: 251-254) i hem pogut veure en diverses de les acusacions presentades en les querelles número 121 i 123 les composicions podien partir de fraus «inventats» pels propis oficials- operaren al marge de la llei, essent conscients que llur posició sempre havia de tendir a ésser defensada des de Barcelona (on allò que veritablement preocupava no era altra cosa que l'exacció dels drets del General, al preu que fos). ${ }^{89}$

87 DGC, vol. VII, p. 64.

88 ACA, Generalitat, Sèrie G, 85, 34, ff. 645-646. Sobre els recursos a les sentències de la Visita del General de Catalunya presentats davant la Reial Audiència de Catalunya, vegeu Torra (2018: 168-170). Segons un memorial que els visitadors enviaren a la reina Marianna d’Àustria l'any 1674, la pràctica de presentar recursos davant la jurisdicció reial a partir de 1652 havia conduït a una situació en la qual la Visita era «de ningún provecho, lo que resulta en gran daño de la Generalidad», ja que «todo se suspende y nada de executa, y las deudas de la Diputazión se imposibilitan de cobrar, con que la Visita es de poco o de ningún beneficio por todas estas causas». ACA, Generalitat, Sèrie G, 6, 15, ff. 78-2 $\mathrm{i}$ 78-3 $3^{\text {a }}$ (11-XII-1674). Citat per Torra (2018: 170).

89 Ara fa uns anys, Miquel Pérez Latre (2004: 145) ja avisà del fet que malgrat que la posició oficial de la Diputació del General era contrària a l'ús del mecanisme de la composició amb l'objectiu de recaptar almenys una part d'allò que realment haurien d'haver pagar les mercaderies que circulaven pel territori, «fos a les primeres ciutats i viles del país -els grans centres consumidors- fos a les àrees frontereres, tot fa pensar que bona part dels fraus detectats eren fruit de connivències entre els defraudadors i oficials del General».

SCRIPTA, Revista internacional de literatura i cultura medieval i moderna, núm. 13 / juny 2019 / pp. 212 - 242 ISSN: 2340-4841 · doi:10.7203/SCRIPTA.13.15482 
Ricard Torra. Territori i relacions institucionals a la Catalunya del Sis-cents. Tres estudis de cas a partir dels processos de la Visita del General de Catalunya

Dit això, considerem que cal anar més enllà del mer estudi de cas presentat ací. Existeix, pensem, la necessitat d'estudiar i comprendre més i millor l'articulació del territori des d'una òptica institucional, dedicant una atenció especial a la pràctica quotidiana dels oficials que la feren possible. Així obres com les que recentment ha coordinat Dantí (2005; 2011; i molt especialment 2015) o la monografia de Garcia Espuche (2001), són unes plataformes immillorables des d'on fer partir aquest l'anàlisi. Però pel que fa a la Diputació del General (única institució la jurisdicció de la qual afectava a tots i cadascun dels habitants del Principat de Catalunya i els Comtats de Rosselló i Cerdanya) encara hi ha molta feina per fer. Tot just comencem a conèixer qüestions com ara la figura dels taulers del General, mentre que altres elements com ara els arrendaments del General i les xarxes d'interessos creades a l'entorn d'aquests si bé s'han estudiat de manera sistemàtica pel que fa a les darreres dècades del segle XVII (Jordà 1982), encara s'hauria d'emprendre l'estudi pel que fa a la primera meitat de la centúria. Però potser el més important seria determinar com s'administraven les col lectes del General durant el segle XVII, a poder ser veure'n les diferències entre la primera i segona meitats i sobretot fer-ho a partir de fons produïdes en la mesura del possible des del territori. L'articulació institucional del territori, en definitiva, ens hauria de permetre comprendre molt millor com s'esdevingué la construcció estatal al Principat durant la darrera etapa de vigència del dret històric català, construcció estatal que, com darrerament s'ha apuntat, no hauria pas estat un procés unidireccional dirigit per les dinasties i els centres de poder polític de l'època moderna, sinó que s'hauria basat en la interacció sorgida a partir de les demandes que diferents grups de poder -elits dirigents, classes dirigents, si es vol- haurien fet al poder central (Holenstein 2009: 4-5).

D'altra banda, pensem que degudament contextualitzats els processos de la Visita del General de Catalunya -juntament amb la resta de documentació produïda per la institució, especialment les sentències- ens han de servir per evidenciar el paper de garant de l'ordre constitucional vigent brandat per la institució al llarg de la seva història, especialment pel que fa a la defensa aferrissada de la legislació acordada pels braços reunits en Corts, fins i tot en els moments més obscurs del segle XVII. En aquest sentit, pensem que els casos dels processos de les querelles número 30 i 42 de la Visita de 1656-1657 són un exemple molt clar d'aquesta voluntat. Com hem pogut veure, malgrat les adversitats generades pel context polític i econòmic posterior al «retorn» de 1652, els dirigents de la Visita del General de Catalunya s'esforçaren per fer complir la literalitat de les normatives aprovades cinquanta anys abans a les Corts Catalanes de 1599. I un cop comprovada l'actitud poc conciliadora dels dirigents de la Diputació del General durant el trienni de 1654-1656 amb els visitadors de 1654-1655, els successors d'aquests darrers no dubtaren en processar els diputats i oïdors de comptes per no haver complert amb una de les seves principals obligacions, això és, la defensa de la legalitat vigent per sobre de contextos i preferències consistorials.

SCRIPTA, Revista internacional de literatura i cultura medieval i moderna, núm. 13 / juny 2019 / pp. 212 - 242 ISSN: 2340-4841 · doi:10.7203/SCRIPTA.13.15482 
Ricard Torra. Territori i relacions institucionals a la Catalunya del Sis-cents. Tres estudis de cas a partir dels processos de la Visita del General de Catalunya

\section{Bibliografia}

\section{Bibliografia primària}

Constitutions fetes per la S.C.R. Magestat del Rey don Phelip Segon, Rey de Castella, de Aragó, etc. en la primera Cort celebrà als cathalans en la ciutat de Barcelona en lo Monastir de S. Francesch en lo any 1599, Barcelona, Gabriel Graells i Geraldo Dotil, (1603).

Capitols dels drets del General del Principat de Cathalunya y Comtats de Rosselló y Cerdanya: fets per la Cort General, celebrada per la bona memòria del Catòlich Rey don Fernando Segon, en lo Capitol de la Seu de Barcelona a VIII de Octubre, any de la Nativitat del Senyor MCCCCXXXI, dins Capitols dels drets y altres coses del General del Principat de Cathalunya y Comtats de Rosselló y Cerdanya fets en Corts generals del any MCCCCXXXI fins en lo any MDLXIIII inclusive, $y$ dels drets que per pràctica y altrament se paguen, Barcelona, Casa Mathevat, (1670).

Capitols per lo redrés del Generaly Casa de la Deputació de Cathalunya, fets en las Corts celebrades en lo Monestir de Sant Francesch de Barcelona per la S.C.R.M. del Serenissim Senyor Rey Don Felip II de Aragó y III de Castella, en lo any 1599, Barcelona, Rafel Figueró, (1704).

\section{Bibliografia secundària}

Andújar, F. \& Feros, A. \& Ponce Leiva, P. (2017) "Corrupción y mecanismos de control en la Monarquía Hispánica: una revisión crítica”, Tiempos Modernos: Revista electrónica de historia moderna, 35 , pp. 284-311.

Buchan B. \& Hill, L. (2014) An intellectual history of political corruption, Palgrave Macmillan.

Capdeferro, J. (2007) “El vigor de les institucions de la terra a la vigília dels Segadors”, dins Albareda, J. (Ed.) Una relació difícil. Catalunya i l'Espanya Moderna (segles XVII-XIX), Barcelona, Base, pp. 47-83.

Capdeferro, J. (2012) Ciència i experiència. El jurista Fontanella (1575-1649) i les seves cartes, Barcelona, Fundació Noguera.

. (2017) Juristes, litigis i poder al Comtat d'Empúries en temps de Jeroni Pujades (1568-1635), Castelló d'Empúries, Ajuntament de Castelló d’Empúries.

Capdeferro, J. \& Serra, E. (2015) Casos davant del Tribunal de Contrafaccions de Catalunya (1702-1713), Barcelona, Parlament de Catalunya - Departament de Justícia.

Cárceles de Gea, B. (2000) Fraude y desobediencia fiscal en la Corona de Castilla (1621-1700), Valladolid, Junta de Castilla y León.

Dantí, J. (coord.) (2005) Ciutats, viles i pobles a la xarxa urbana de la Catalunya moderna, Barcelona, Rafael Dalmau.

- (coord.) (2011) Les xarxes urbanes a la Catalunya dels segles XVI i XVII, Barcelona, Rafael Dalmau.

—. (coord.) (2015) L'articulació del territori a la Catalunya moderna, Barcelona, Rafael Dalmau.

SCRIPTA, Revista internacional de literatura i cultura medieval i moderna, núm. 13 / juny 2019 / pp. 212 - 242 
Ricard Torra. Territori i relacions institucionals a la Catalunya del Sis-cents. Tres estudis de cas a partir dels processos de la Visita del General de Catalunya

Dietaris de la Generalitat de Catalunya, vols. VI i VII, Barcelona, Generalitat de Catalunya (2000-2002).

Duran, M. (2003) “Els arrendaments dels drets de bolla: un indicador vàlid per mesurar la producció i el consum de teixits?, Butlletí de la Societat Catalana d'Estudis Històrics, 14, pp. 9-39.

Espino, A. (2014) Las guerras de Cataluña. El teatro de Marte, 1652-1714, Madrid, Edaf.

Felipó, A. (2003) “Las Visitas de inspección a la ciudad de Valencia durante el siglo XVI", Studia Historica, Historia Moderna, 25, pp. 241-267.

Ferro, V. (1987) El Dret Públic Català. Les institucions a Catalunya fins al Decret de Nova Planta, Vic, Eumo.

Garriga, C. (1991) “Control y disciplina de los oficiales públicos en Castilla: la 'Visita' del ordenamiento de Toledo (1480)", Anuario de Historia del Derecho Español, 61, pp. 215-390.

Gómez González, I. (2016) "Entre la corrupción y la venalidad: don Pedro Valle de la Cerda y la visita al consejo de hacienda de 1643", dins Andújar, F.; Ponce Leiva, P. (Eds.) Mérito, venalidady corrupción en España y América, siglos XVII y XVIII, València, Albatros, pp. 235-249.

González Peinado, C. (2010) "El inicio del juicio de residencia a don Alonso de Granada Venegas (Ocaña, Toledo, 1597): algunas notas sobre su procedimiento", Espacio, tiempo y forma. Serie IV, Historia moderna, 23, pp. 41-57.

Garcia Espuche, A. (1998) Un siglo decisivo: Barcelona y Cataluña, 1550-1640, Madrid, Alianza.

Gil, X. (2001) "La Corona de Aragón a finales del siglo XVII: a vueltas con el neoforalismo", dins Fernández Albaladejo, P. (Ed.) Los Borbones. Dinastía y memoria de nación en la España del siglo XVIII, Madrid, Casa de Velázquez-Marcial Pons, pp. 97-115.

Gras, M. (2000) “Territori i fiscalitat a la Catalunya moderna. Col lectes i veredes", dins V Congrés Internacional d'Història Local de Catalunya. L'estructuració territorial de Catalunya. Els eixos cohesionadors de l'espai, Barcelona, L’Avenç, pp. 399-409.

Herzog, T. (2000) Ritos de control, prácticas de negociación: pesquisas, visitas y residencias y las relaciones entre Quito y Madrid (1650-1750), Madrid, Fundación Hernando de Larramendi.

Hespanha, A. M. (1989) Visperas del Leviatán: instituciones y poder politico (Portugal, siglo XVII), Madrid, Taurus.

Holenstein, A. (2009) "Introduction: Empowering Interactions: Looking at Statebuilding from Below", dins Blockmans, W.; Holenstein, A.; Mathieu, J. (Eds.) Empowering Interactions. Political Cultures and the Emergence of the State in Europe 1300-1900, Ashgate, pp. 1-31.

Jordà, A. (1982) "Els ingressos fiscals de la Generalitat de Catalunya a la segona meitat del segle XVII", Estudis Històrics i Documents dels Arxius de Protocols, 10, pp. 163-204.

Lalinde, J. (1965) “La 'purga de taula”, dins DD.AA., Homenaje a Jaime Vicens Vives, tomo I, Barcelona, Universitat de Barcelona, pp. 499-523. 
Ricard Torra. Territori i relacions institucionals a la Catalunya del Sis-cents. Tres estudis de cas a partir dels processos de la Visita del General de Catalunya

Llinàs, P. (1990) "La Visita del General: el procedimiento de control de los funcionarios dependientes de la Diputació del General de Catalunya (1653-1701)", Pedralbes, Revista d'Història moderna, 10 , pp. 177-193.

Llobet, S. (1990) "La pèrdua de les Galeres de Catalunya l'any 1623”, Butlletí de la Reial Acadèmia de les Bones Lletres de Barcelona, 42, pp. 117-160.

Malaprade, S. (2017) "Crédito y corrupción. La visita al Consejo de Hacienda de 1643", Tiempos Modernos: Revista electrónica de historia moderna, 35, pp. 363-387.

Olivares, J. (2000) Viles, pagesos i senyors a la Catalunya dels Àustria, Lleida, Pagès Editors.

Palos, J. (1994) Catalunya a l'Imperi dels Àustria. La pràctica de govern (segles XVI i XVII), Lleida, Pagès Editors.

Pérez Latre, M. (2004) La Generalitat de Catalunya en temps de Felip II. Politica, administració i territori, Catarroja, Afers.

Peytavin, M. (2003) Visite et gouvernement dans le royaume de Naples (XVTè-XVIIè siècles), Madrid, Casa de Velázquez.

Rovito, P. (1981) Respublica dei togati. Giuristi e societa' nella Napoli del seicento, Nàpols, Jovene Editore.

Sánchez Marcos, F. (1983) Cataluña y el gobierno central tras la Guerra de los Segadores (1652-1679), Barcelona, Publicacions i edicions de la Universitat de Barcelona.

Serra, E. (1997) “Catalunya després del 1652: recompenses, censura i repressió”, Pedralbes. Revista d'Història Moderna, 17, pp. 191-216.

- (2006) "Les galeres de la Generalitat: només una política defensiva?”, dins Actes del III Congrés d'Història Marítima de Catalunya. Museu Marítim de Barcelona, Barcelona, 22, 23 i 24 de novembre de 2006, Actes en format CD-ROM.

—. (2011a) “Territori i inspecció fiscal: la Visita del General de 1600”, dins Dantí, J. (Coord.) Les xarxes urbanes a la Catalunya dels segles XVI $i$ XVII, Barcelona, Rafael Dalmau, pp. 169-284.

(2011b) "La Generalitat de Catalunya entre 1652 i 1700”, dins Ferrer i Mallol, T. (Dir.) Història de la Generalitat de Catalunya. Dels origens medievals a l'actualitat, 650 anys, Barcelona, Institut d'Estudis Catalans - Generalitat de Catalunya.

Simon, A. (2011) Del 1640 al 1705. L'autogovern de Catalunya i la classe dirigent catalana en el joc de la política internacional europea, València, Publicacions de la Universitat de València.

Torra, R. (2014a) "La Visita del General de Catalunya. Una institució desconeguda (segles XVIXVIII)", Afers, fulls de recerca i pensament, 77, pp. 149-171.

(2014b) "Mites o realitats? Sobre el paper de les Corts Catalanes altmodernes com a generadores de dret. El cas de la Visita del General", Estudis. Revista de Història Moderna, 40, pp. 115-132.

SCRIPTA, Revista internacional de literatura i cultura medieval i moderna, núm. 13 / juny 2019 / pp. 212 - 242 
Ricard Torra. Territori i relacions institucionals a la Catalunya del Sis-cents. Tres estudis de cas a partir dels processos de la Visita del General de Catalunya

- (2015) "La fiscalización de la actividad de los oficiales de la Generalitat de Cataluña en la época moderna. la Visita del General de Cataluña y su funcionamiento", Cuadernos de Historia del Derecho, 22, pp. 295-317.

- (2016) "El juego de las instituciones. Políticas de la Visita del General de Catalunya durante la primera mitad del siglo XVII", Tiempos Modernos: Revista electrónica de historia moderna, 32, pp. 249-279.

(2017) “¿Más allá del control de la corrupción? Las sentencias de visita como base para nuevos ordenamientos jurídicos: el impreso sobre las galeras de 1621”, dins Gil, F; Villarreal, A. (Eds.) Estudios sobre la corrupción en España y América (siglos XVI-XVIII), Almeria, EDUAL, pp. 171-188.

—. (2018) “La reconfiguración del espacio político catalán a partir de 1652: ¿Hacia un constitucionalismo más ficticio que real?, Magallánica, Revista de Historia Moderna, 4/8, pp. 157180.

Torras i Ribé, J. (1993) "El control polític de les insaculacions del Consell de Cent de Barcelona (1652-1700), Pedralbes, Revista d'Història Moderna, 13-1, pp. 457-468.

Waquet, J. (1991) Corruption. Ethics and power in Florence, 1600-1700, Pennsylvania, Pennsylvania University Press. 